\title{
Total Synthesis of (+)-Trachyspic Acid 19-n-Butyl Ester.
}

\author{
Alex A. Rafaniello and Mark A. Rizzacasa.* \\ School of Chemistry and Bio21 Molecular Science and Biotechnology Institute, The University of \\ Melbourne, Melbourne, Victoria, 3010, Australia.
}

\section{Supporting Information}

\section{Experimental Section}

General

Preparation of di- $n$-butyl acetylenedicarboxylate 7

Preparation of cyclobutene di- $n$-butyl ester $\mathbf{5}$

Preparation of bicyclic lactone $\mathbf{8}$

Preparation of tosylate $\mathbf{1 0}$

Preparation of alkene $\mathbf{1 1}$

Preparation of di-tert-butyl ester $\mathbf{1 2}$

Preparation of TMS ether 13

Preparation of vinyl iodide $\mathbf{1 5}$

Preparation of acetal 4

Preparation of enone 16

Preparation of trachyspic acid di-tert-butyl-19-n-butyl ester 17

Preparation of trachyspic acid 19-n-butyl ester 1

Table 1: ${ }^{1} \mathrm{H}$ NMR and ${ }^{13} \mathrm{C}$ NMR data for natural and synthetic 1 


\section{General}

All reactions were performed under an inert argon or nitrogen atmosphere in flame-dried or ovendried $\left(150{ }^{\circ} \mathrm{C}\right)$ glassware. Reactions were heated using Radleys round bottom flask Heat-on blocks with thermostatic control. Anhydrous tetrahydrofuran (THF), diethyl ether ( $\left.\mathrm{Et}_{2} \mathrm{O}\right)$ and dichloromethane (DCM) were obtained from a solvent dispensing system where solvents were dried by passage through two packed columns of neutral alumina under argon. Dry methanol (MeOH) was distilled from magnesium methoxide or $\mathrm{CaSO}_{4}$ and stored over $4 \AA$ molecular sieves. Dry triethylamine $\left(\mathrm{NEt}_{3}\right)$ and acetonitrile $(\mathrm{MeCN})$ were freshly distilled from calcium hydride under nitrogen atmosphere. Diisopropylamine (DIPA) was distilled from $\mathrm{NaOH}$ under nitrogen or argon atmosphere immediately prior to use. Hexamethylphosphoramide (HMPA) and $N, N$ dimethylformamide (DMF) were dried by storage over $4 \AA$ molecule sieves. All other commercial reagents were used as received. Brine refers to a saturated aqueous solution of $\mathrm{NaCl}$ and petrol refers to petroleum spirits of the fraction boiling between 40 and $60^{\circ} \mathrm{C}$. Flash chromatography was carried out using silica gel 60. Analytical thin layer chromatography (TLC) was conducted on aluminium backed plates ( $2 \mathrm{~mm}$ silica gel $60 \mathrm{~F}_{254}$ ) and chromatograms were visualised under UV light ( $365 \mathrm{~nm}$ ) and with solutions of $20 \% \mathrm{w} / \mathrm{w}$ phosphomolybdic acid in ethanol (PMA), 20\% w/w potassium permanganate in water (PP) or 5\% w/v cerium (IV) ammonium molybdate and $1 \% \mathrm{w} / \mathrm{v}$ ceric sulphate in dilute sulphuric acid (CAM). Melting points were obtained in open capillaries and are uncorrected. Optical rotations were recorded at $22{ }^{\circ} \mathrm{C}$ in a $10.0 \mathrm{~cm}$ microcell and units are deg. $\mathrm{cm}^{2} \mathrm{~g}^{-1}$. Infrared (IR) spectra were recorded using an attenuated total reflectance (ATR) attachment. High-resolution mass spectra (HRMS) were obtained using electrospray ionisation (ESI). Nuclear magnetic resonance (NMR) spectra were recorded in $\mathrm{CDCl}_{3}$ on a 400,500 or $600 \mathrm{MHz}$ spectrometer and chemical sifts $(\delta)$ were internally referenced to the residual proton resonance $(\delta 7.26 \mathrm{ppm})$.

Di-n-butyl acetylenedicarboxylate 7 (modifed procedure from that reported by Gogoi et al) ${ }^{1}$

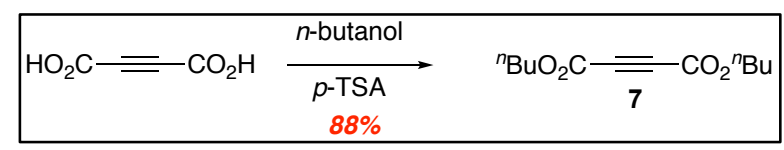

To a solution of acetylenedicarboxylic acid $(4.00 \mathrm{~g}, 35.1 \mathrm{mmol})$ in toluene $(80 \mathrm{~mL})$ was added $p$ toluenesulfonic acid monohydrate $(0.40 \mathrm{~g}, 2.1 \mathrm{mmol})$ and $n$-butanol $(10.6 \mathrm{~mL}, 77.0 \mathrm{mmol})$. The reaction mixture was stirred at reflux in a Dean-Stark apparatus for $4 \mathrm{~h}$, then cooled and poured into sat. $\mathrm{NaCl}(40 \mathrm{~mL})$ and stirred until two layers formed. The aqueous phase was extracted twice with $n$-hexane $(2 \times 40 \mathrm{~mL})$. The combined organic extracts were washed with sat. $\mathrm{NaHCO}_{3}$, water and dried $\left(\mathrm{MgSO}_{4}\right)$ and concentrated to give di- $n$-butyl acetylenedicarboxylate $7^{1}(6.94 \mathrm{~g}, 88 \%)$ as a yellow liquid. ${ }^{1} \mathrm{H}$ NMR $\delta(600 \mathrm{MHz}) 0.94(\mathrm{t}, J=7.4 \mathrm{~Hz}, 3 \mathrm{H}), 1.41$ (sextet, $\left.J=7.6 \mathrm{~Hz}, 2 \mathrm{H}\right), 1.67$ 
(pentet, $J=7.6 \mathrm{~Hz}, 2 \mathrm{H}), 4.24(\mathrm{t}, J=6.7 \mathrm{~Hz}) ;{ }^{13} \mathrm{C} \mathrm{NMR} \delta(150 \mathrm{MHz}) 13.7,19.1,30.4,67.0,74.8$, 152.1; HRMS (ESI) calculated for $\mathrm{C}_{12} \mathrm{H}_{19} \mathrm{O}_{4}[\mathrm{M}+\mathrm{H}]^{+} 227.1283$, found 227.1278.

\section{Cyclobutene di-n-butyl ester 5}

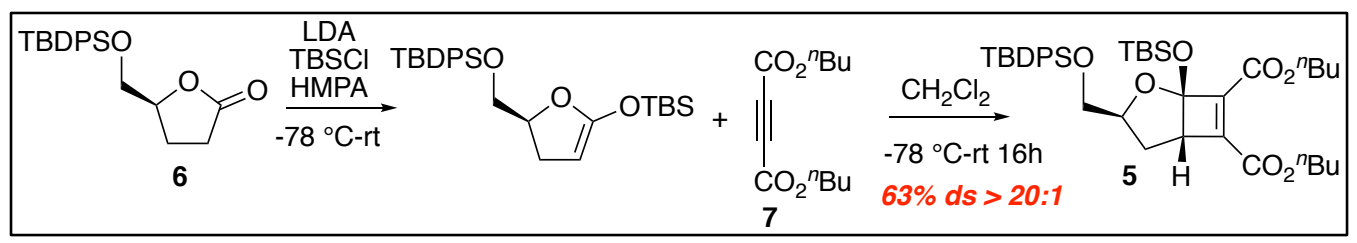

A solution of LDA was prepared by addition of $n-\operatorname{BuLi}(2.45 \mathrm{M}, 6.9 \mathrm{~mL}, 16.9 \mathrm{mmol})$ to a solution of diisopropylamine $(2.5 \mathrm{~mL}, 17.8 \mathrm{mmol})$ in THF $(13.5 \mathrm{~mL})$ cooled to $-78^{\circ} \mathrm{C}$. The solution was warmed to $0{ }^{\circ} \mathrm{C}$ for 15 minutes until a pale-yellow colour persisted, and cooled again to $-78{ }^{\circ} \mathrm{C}$. A solution of lactone $\mathbf{6}^{2}(3.00 \mathrm{~g}, 8.47 \mathrm{mmol})$ in THF $(6 \mathrm{~mL})$ was added dropwise and the mixture was stirred at $78^{\circ} \mathrm{C}$ for $1.5 \mathrm{~h}$. A solution of TBSCl $(1.67 \mathrm{~g}, 11.1 \mathrm{mmol})$ and HMPA $(3 \mathrm{~mL})$ in THF $(3 \mathrm{~mL})$ was then added dropwise, allowed to stir at $-78^{\circ} \mathrm{C}$ for $30 \mathrm{~min}$, then allowed to warm to rt and stirred for $1 \mathrm{~h}$. The mixture was cooled to $0{ }^{\circ} \mathrm{C}$, diluted with pentane $(15 \mathrm{~mL})$, quenched with $\mathrm{H}_{2} \mathrm{O}(15 \mathrm{~mL})$ and the organic layer washed with water $(3 \times 10 \mathrm{~mL})$ and brine $(3 \times 10 \mathrm{~mL})$, dried $\left(\mathrm{Na}_{2} \mathrm{SO}_{4}\right)$ and concentrated. The crude residue was immediately dissolved in $\mathrm{CH}_{2} \mathrm{Cl}_{2}(4 \mathrm{~mL})$ and cooled to $-78{ }^{\circ} \mathrm{C}$. A solution of di- $n$-butyl acetylenedicarboxylate $7(4.00 \mathrm{~g}, 17.7 \mathrm{mmol})$ in $\mathrm{CH}_{2} \mathrm{Cl}_{2}(3 \mathrm{~mL})$ was added dropwise, and the reaction mixture was stirred for $16 \mathrm{~h}$, while warming to $\mathrm{rt}$. The solvent was removed and purification by flash column chromatography (2.5 - 5\% EtOAc/petrol) afforded cyclobutene diester $5(3.68 \mathrm{~g}, 63 \%,>20: 1 \mathrm{dr})$ as a pale-yellow oil. $[\alpha]_{D}^{21}=-12.0\left(c 0.88, \mathrm{CH}_{2} \mathrm{Cl}_{2}\right) ; v_{\max } 2059,2931$, 2859, 1721, 1648, 1311, 1276, 1250, 1113, 1058, $702 \mathrm{~cm}^{-1}$; ${ }^{1} \mathrm{H}$ NMR $\delta$ (600 MHz) 0.11 (s, 3H), 0.17 (s, 3H), $0.88(\mathrm{~s}, 9 \mathrm{H}), 0.92(\mathrm{t}, J=7.4 \mathrm{~Hz}, 3 \mathrm{H}), 0.95$ (t, $J=7.4 \mathrm{~Hz}), 1.05(\mathrm{~s}, 9 \mathrm{H}), 1.41(\mathrm{~m}, 4 \mathrm{H}), 1.66$ (m, 4H), $1.77(\mathrm{ddd}, J=13.0,11.1,7.8 \mathrm{~Hz}, 1 \mathrm{H}), 1.93(\mathrm{dd}, J=13.0,5.0 \mathrm{~Hz}, 1 \mathrm{H}), 3.27$ (d, $J=7.7 \mathrm{~Hz}$, 1H), 3.83 (app. qd, $J=9.7,4.5 \mathrm{~Hz}, 2 \mathrm{H}), 4.00$ (dq, $J=10.5,5.1 \mathrm{~Hz}, 1 \mathrm{H}), 4.15-4.25$ (m, 4H), $7.36-$ $7.39(\mathrm{~m}, 4 \mathrm{H}), 7.41-7.44(\mathrm{~m}, 2 \mathrm{H}), 7.65-7.68(\mathrm{~m}, 4 \mathrm{H}),{ }^{13} \mathrm{C}$ NMR $\delta(151 \mathrm{MHz})-3.3,-3.0,13.82$, 13.84, 17.9, 19.21, 19.25, 19.4, 25.8, 26.9, 28.4, 30.68, 30.72, 55.36, 55.39, 64.8, 65.3, 78.9, 106.1, 127.8, 127.8, 129.82, 129.83, 133.4, 133.5, 135.8, 135.8, 140.8, 142.4, 160.4, 162.3. HRMS (ESI) calculated for $\mathrm{C}_{39} \mathrm{H}_{59} \mathrm{O}_{7} \mathrm{Si}_{2}[\mathrm{M}+\mathrm{H}]^{+}$695.3799, found 695.3797 .

\section{Bicyclic lactone 7}

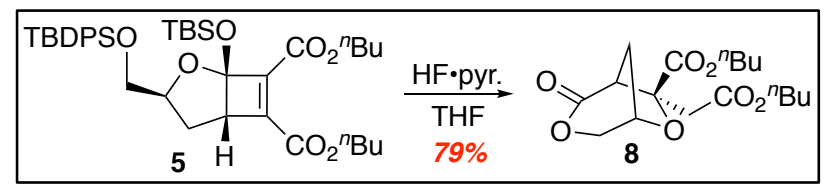

To a solution of cyclobutene diester $5(980 \mathrm{mg}, 1.41 \mathrm{mmol})$ in THF $(28 \mathrm{~mL})$ at $0{ }^{\circ} \mathrm{C}$ was added $70 \%$ HF.pyridine $(70 \%, 0.74 \mathrm{~mL}, 28.2 \mathrm{mmol})$. The mixture was allowed to warm to $\mathrm{rt}$ and stirred for 4 
days, then quenched with solid $\mathrm{NaHCO}_{3}$, filtered through Celite and concentrated. Purification by flash column chromatography $(20$ - 30\% EtOAc/petrol) afforded lactone 8 (381 mg, 79\%) as a colourless oil. $[\alpha]_{D}^{26}=+32.0\left(c 0.87, \mathrm{CH}_{2} \mathrm{Cl}_{2}\right) ;{ }^{1} \mathrm{H} \mathrm{NMR} \delta(600 \mathrm{MHz}) 0.92(\mathrm{t}, J=7.4 \mathrm{~Hz}, 3 \mathrm{H}), 0.94$ (t, $J=7.4 \mathrm{~Hz}, 3 \mathrm{H}), 1.36(\mathrm{~m}, 4 \mathrm{H}), 1.62(\mathrm{~m}, 4 \mathrm{H}), 2.15(\mathrm{~d}, J=12.3 \mathrm{~Hz}), 2.51$ (dddd, $J=12.2,6.0,4.2$, $\left.1.8\left(J_{\mathrm{W}}\right) \mathrm{Hz}, 1 \mathrm{H}\right), 2.75$ and $3.17(\mathrm{ABq}, J=16.8 \mathrm{~Hz}, 2 \mathrm{H}), 3.37(\mathrm{~d}, J=4.0 \mathrm{~Hz}, 1 \mathrm{H}), 4.09$ (t, $J=6.7 \mathrm{~Hz}$, $2 \mathrm{H}), 4.17(\mathrm{td}, J=6.7,1.1 \mathrm{~Hz}, 2 \mathrm{H}), 4.22(\mathrm{dd}, J=11.8,1.9 \mathrm{~Hz}, 1 \mathrm{H}), 4.34(\mathrm{dt}, J=11.8,1.0 \mathrm{~Hz}, 1 \mathrm{H})$, $4.70(\mathrm{~d}, J=5.8 \mathrm{~Hz}, 1 \mathrm{H}) ;{ }^{13} \mathrm{C}$ NMR $\delta(151 \mathrm{MHz}) 13.7,19.1,19.2,28.8,30.5,30.6,40.6,49.3$, 65.1,66.1, 74.2, 75.5, 84.2, 168.4, 169.3, 170.8; HRMS (ESI) calculated for $\mathrm{C}_{17} \mathrm{H}_{27} \mathrm{O}_{7}[\mathrm{M}+\mathrm{H}]^{+}$ 343.1757 , found 343.1752 .

\section{Tosylate 10}

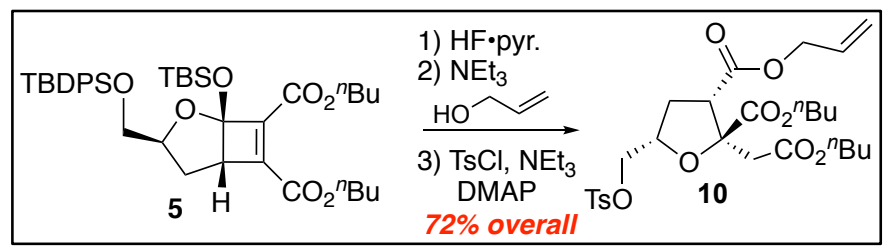

To a solution of cyclobutene diester $5(1.70 \mathrm{~g}, 2.44 \mathrm{mmol})$ in THF $(45 \mathrm{~mL})$ at $0{ }^{\circ} \mathrm{C}$ was added $70 \%$ HF.pyridine $(70 \%, 1.35 \mathrm{~mL}, 52.0 \mathrm{mmol})$. The reaction mixture was allowed to warm to rt and stirred for 3 days, then quenched with solid $\mathrm{NaHCO}_{3}$, filtered through Celite and concentrated. The crude residue was dissolved in allyl alcohol $(2.7 \mathrm{~mL}, 39 \mathrm{mmol})$ and to this was added $\mathrm{Et}_{3} \mathrm{~N}(1.4 \mathrm{~mL}, 10$ mmol). The resultant solution was stirred at $50{ }^{\circ} \mathrm{C}$ for $16 \mathrm{~h}$, then diluted with EtOAc. The organic layer washed with water, brine, then dried $\left(\mathrm{Na}_{2} \mathrm{SO}_{4}\right)$ and concentrated. The crude residue was immediately dissolved in $\mathrm{CH}_{2} \mathrm{Cl}_{2}(20 \mathrm{~mL}$ ), and to this was added DMAP (46 mg, $0.38 \mathrm{mmol}$ ). The solution was cooled to $0{ }^{\circ} \mathrm{C}$, and to this was added $\mathrm{Et}_{3} \mathrm{~N}(1.0 \mathrm{~mL}, 7.1 \mathrm{mmol})$ and $\mathrm{TsCl}(703 \mathrm{mg}, 3.69$ mmol). The reaction mixture was warmed to $\mathrm{rt}$ and allowed to stir for $16 \mathrm{~h}$, then quenched with $1 \mathrm{M}$ $\mathrm{HCl}$. The organic phase was washed with sat. aq. $\mathrm{NaHCO}_{3}$, water, brine, then dried $\left(\mathrm{Na}_{2} \mathrm{SO}_{4}\right)$ and concentrated. Purification by flash column chromatography (20\% EtOAc/petrol) afforded tosylate 10 $(0.98 \mathrm{~g}, 72 \%)$ as a pale yellow oil. $[\alpha]_{D}^{20}=+6.5\left(c 1.2, \mathrm{CH}_{2} \mathrm{Cl}_{2}\right) ;{ }^{1} \mathrm{H} \mathrm{NMR} \delta(600 \mathrm{MHz}) 0.91(\mathrm{t}, J=$ $7.4 \mathrm{~Hz}, 3 \mathrm{H}), 0.93$ (t, $J=7.4 \mathrm{~Hz}, 3 \mathrm{H}), 1.34$ (m, 4H), 1.56 (m, 2H), 1.63 (m, 2H), 2.16 (ddd, $J=13.7$, 7.0, 6.6 Hz, 1H), 2.33 (ddd, $J=13.1,8.3,7.3 \mathrm{~Hz}, 1 \mathrm{H}), 2.45$ (s, 3H), 2.75 (ABq, $J=16.5 \mathrm{~Hz}, 1 \mathrm{H})$, $2.94(\mathrm{ABq}, J=16.5 \mathrm{~Hz}, 1 \mathrm{H}), 3.41(\mathrm{dd}, J=8.3,6.6 \mathrm{~Hz}, 1 \mathrm{H}), 4.03(\mathrm{~m}, 2 \mathrm{H}), 4.16(\mathrm{~m}, 4 \mathrm{H}), 4.43(\mathrm{tt}, J$ $=7.4,5.5 \mathrm{~Hz}, 1 \mathrm{H}), 4.58$ (app. tqd, $J=11.6,6.0,1.3 \mathrm{~Hz}, 2 \mathrm{H}), 5.27$ (dq, $J=10.4,1.2 \mathrm{~Hz}, 1 \mathrm{H}), 5.34$ (dq, $J=17.2,1.4 \mathrm{~Hz}, 1 \mathrm{H}), 5.89(\mathrm{ddt}, J=17.2,10.4,6.0 \mathrm{~Hz}, 1 \mathrm{H}), 7.33(\mathrm{~m}, 2 \mathrm{H}), 7.79(\mathrm{~m}, 2 \mathrm{H}) ;{ }^{13} \mathrm{C} \mathrm{NMR} \delta$ (151 MHz) 13.8, 13.8, 19.1, 19.2, 21.8, 30.55, 30.61, 31.7, 39.5, 50.1, 64.9, 65.9, 66.2, 70.4, 77.0, 85.4, 119.4, 128.2, 130.0, 131.5, 132.9, 145.0, 169.5, 171.0, 171.7; HRMS (ESI) calculated for $\mathrm{C}_{27} \mathrm{H}_{39} \mathrm{O}_{10} \mathrm{~S}[\mathrm{M}+\mathrm{H}]^{+}$555.2264, found 555.2261. 


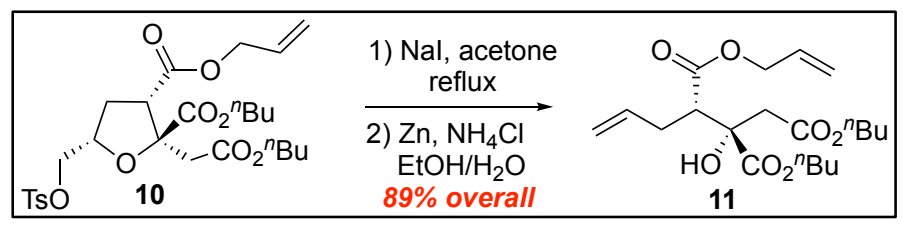

A solution of tosylate $10(871 \mathrm{mg}, 1.57 \mathrm{mmol})$ and $\mathrm{NaI}(4.72 \mathrm{~g}, 31.5 \mathrm{mmol})$ in acetone $(18 \mathrm{~mL})$ was stirred at reflux for $16 \mathrm{~h}$ then cooled, filtered through Celite ${ }^{\circledR}$ and concentrated. The crude residue was dissolved in 95\% EtOH: $\mathrm{H}_{2} \mathrm{O}(32 \mathrm{~mL})$ and to this was added activated zinc powder $(1.02 \mathrm{~g}, 15.6$ $\mathrm{mmol}$ ) and $\mathrm{NH}_{4} \mathrm{Cl}(426 \mathrm{mg}, 7.89 \mathrm{mmol})$, and the suspension was stirred for $2 \mathrm{~h}$ at $\mathrm{rt}$. The suspension was diluted with EtOAc and filtered through Celite ${ }^{\circledR}$, concentrated, redissolved in EtOAc, and washed with sat. $\mathrm{NaHCO}_{3}, \mathrm{H}_{2} \mathrm{O}$, brine, then dried $\left(\mathrm{Na}_{2} \mathrm{SO}_{4}\right)$ and concentrated. Purification by flash column chromatography (10\% EtOAc/petrol) afforded alkene 11 (535 mg, 89\%) as a colourless oil. $[\alpha]_{D}^{18}=+8.8\left(c 1.3, \mathrm{CH}_{2} \mathrm{Cl}_{2}\right) ;{ }^{1} \mathrm{H} \mathrm{NMR} \delta(500 \mathrm{MHz}) 0.91(\mathrm{t}, J=7.4 \mathrm{~Hz}, 3 \mathrm{H}), 0.93(\mathrm{t}, J=7.4 \mathrm{~Hz}, 3 \mathrm{H})$, $1.36(\mathrm{~m}, 4 \mathrm{H}), 1.58(\mathrm{~m}, 2 \mathrm{H}), 1.65(\mathrm{~m}, 2 \mathrm{H}), 2.29(\mathrm{~m}, 1 \mathrm{H}), 2.55(\mathrm{td}, J=12.8,7.6 \mathrm{~Hz}, 1 \mathrm{H}), 2.75(\mathrm{ABq}$, $J=16.4 \mathrm{~Hz}, 1 \mathrm{H}), 2.82(\mathrm{dd}, J=11.6,3.4 \mathrm{~Hz}, 1 \mathrm{H}), 3.09$ (ABq, $J=16.4 \mathrm{~Hz}, 1 \mathrm{H}), 3.98$ (s, 1H), 4.07 (t, $J=6.7 \mathrm{~Hz}, 2 \mathrm{H}), 4.20(\mathrm{~m}, 2 \mathrm{H}), 4.59$ (qd, $J=14.0,5.8 \mathrm{~Hz}, 2 \mathrm{H}), 5.02(\mathrm{~d}, J=10.2 \mathrm{~Hz}, 1 \mathrm{H}), 5.07$ (dd, $J$ $=17.1,1.2 \mathrm{~Hz}, 1 \mathrm{H}), 5.24(\mathrm{dd}, J=10.5,1.0 \mathrm{~Hz}, 1 \mathrm{H}), 5.34(\mathrm{dd}, J=17.2,1.2 \mathrm{~Hz}, 1 \mathrm{H}), 5.69(\mathrm{ddt}, J=$ 17.0, 10.2, $6.9 \mathrm{~Hz}, 1 \mathrm{H}), 5.90$ (ddt, $J=16.9,10.8,6.0 \mathrm{~Hz}) ;{ }^{13} \mathrm{C} \mathrm{NMR} \delta(125 \mathrm{MHz}) 13.78,13.81,19.19$, 19.20, 30.5, 30.6, 31.6, 41.2, 53.5, 65.0, 65.8, 66.5, 75.6, 117.7, 118.9, 131.9, 134.6, 170.7, 171.4, 173.6; HRMS (ESI) calculated for $\mathrm{C}_{20} \mathrm{H}_{33} \mathrm{O}_{7}[\mathrm{M}+\mathrm{H}]^{+}$385.2226, found 385.2222.

\section{Di-tert-butyl ester 12}

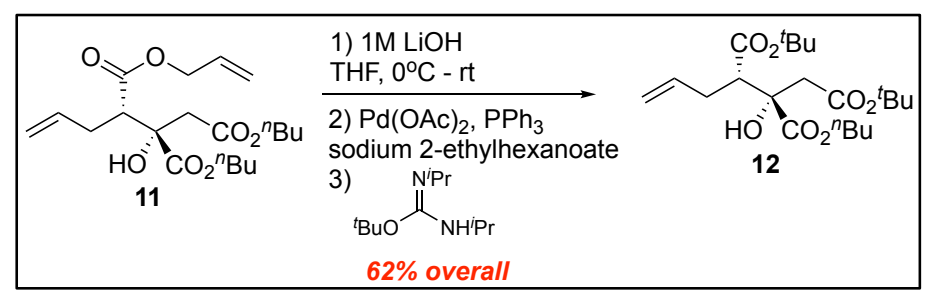

To a solution of triester $11(42.9 \mathrm{mg}, 0.112 \mathrm{mmol})$ in THF $(1.6 \mathrm{~mL})$ at $0{ }^{\circ} \mathrm{C}$ was added $1 \mathrm{M} \mathrm{LiOH}$ $(0.33 \mathrm{~mL}, 0.33 \mathrm{mmol})$. The reaction mixture was warmed to $\mathrm{rt}$ and stirred for $2 \mathrm{~h}$, then quenched with $1 \mathrm{M} \mathrm{HCl}$ (ca. $1 \mathrm{~mL}$ ) and the solvent was removed. The crude residue was immediately dissolved in acetone $(1 \mathrm{~mL})$ and to this was added $\mathrm{Pd}(\mathrm{OAc})_{2}(10.0 \mathrm{mg}, 0.045 \mathrm{mmol}), \mathrm{PPh}_{3}(48 \mathrm{mg}, 0.18 \mathrm{mmol})$ and sodium 2-ethylhexanoate $(4.0 \mathrm{mg}, 0.024 \mathrm{mmol})$. The reaction mixture was stirred at $\mathrm{rt}$ for $40 \mathrm{~h}$, then diluted with EtOAc and acidified with $1 \mathrm{M} \mathrm{HCl}$. The aqueous layer was extracted with EtOAc, and the combined organic extracts washed with water, brine, dried $\left(\mathrm{Na}_{2} \mathrm{SO}_{4}\right)$ and concentrated. The crude diacid was purified by flash column chromatography (80:20:1 EtOAc:petrol:AcOH as eluent). This material $(32.3 \mathrm{mg})$ was dissolved in $\mathrm{CH}_{2} \mathrm{Cl}_{2}(3 \mathrm{~mL})$, cooled to $0{ }^{\circ} \mathrm{C}$, and to this was added $N, N^{\prime}-$ diisopropyl-O-tert-butylisourea $(0.14 \mathrm{~mL}, 0.67 \mathrm{mmol})$. The reaction mixture was warmed to $\mathrm{rt}$ and 
stirred to $16 \mathrm{~h}$, then diluted with $\mathrm{CH}_{2} \mathrm{Cl}_{2}$ (ca. $4 \mathrm{~mL}$ ), filtered through Celite and concentrated. Purification by flash column chromatography (5\% EtOAc/petrol) afforded triester 12 (27.8 mg, 62\%) as a colourless oil. $[\alpha]_{D}^{19}=+2.7\left(1.4 c, \mathrm{CH}_{2} \mathrm{Cl}_{2}\right) ;{ }^{1} \mathrm{H}$ NMR $\delta(600 \mathrm{MHz}) 0.94(\mathrm{t}, J=7.4 \mathrm{~Hz}, 3 \mathrm{H}), 1.38$ (m, 2H), 1.42 (s, 9H), 1.44 (s, 9H), 1.67 (m, 2H), 2.22 (dddt, $J=14.1,6.2,3.3,1.6 \mathrm{~Hz}, 1 \mathrm{H}), 2.49$ (dddt, $J=14.1,11.7,7.5,1.1 \mathrm{~Hz}, 1 \mathrm{H}), 2.62(\mathrm{ABq}, J=16.1 \mathrm{~Hz}, 1 \mathrm{H}), 2.65(\mathrm{dd}, J=11.6,3.5 \mathrm{~Hz}, 1 \mathrm{H})$, $3.00(\mathrm{ABq}, J=16.1 \mathrm{~Hz}, 1 \mathrm{H}), 4.02(\mathrm{~s}, 1 \mathrm{H}), 4.18(\mathrm{dt}, J=10.8,6.6 \mathrm{~Hz}, 1 \mathrm{H}), 4.23$ (dt, $J=10.7,6.8 \mathrm{~Hz})$, $5.01(\mathrm{dq}, J=10.2,1.4 \mathrm{~Hz}, 1 \mathrm{H}), 5.06(\mathrm{dq}, J=17.1,1.6 \mathrm{~Hz}), 5.70(\mathrm{dddd}, J=17.1,10.1,7.5,6.2,1 \mathrm{H})$; ${ }^{13} \mathrm{C}$ NMR $\delta$ (100 MHz) 13.8, 19.3, 28.1, 28.2, 30.6, 31.9, 42.6, 54.0, 66.2, 75.9, 81.7, 81.8, 117.2, 136.0, 169.9, 170.9, 173.7; HRMS (ESI) calculated for $\mathrm{C}_{21} \mathrm{H}_{36} \mathrm{NaO}_{7}[\mathrm{M}+\mathrm{Na}]^{+} 423.2359$, found 423.2352 .

\section{TMS ether 13}

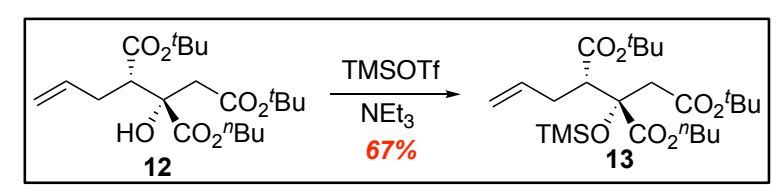

Triethylamine $(0.30 \mathrm{~mL}, 2.2 \mathrm{mmol})$ was added to a solution of alcohol 12 (264 $\mathrm{mg}, 0.66 \mathrm{mmol})$ in $\mathrm{CH}_{2} \mathrm{Cl}_{2}(4.7 \mathrm{~mL})$ at $-15{ }^{\circ} \mathrm{C}$. TMSOTf $(183 \mu \mathrm{L}, 1.0 \mathrm{mmol})$ was added dropwise, and the solution was stirred for $2 \mathrm{~h}$ at $-15{ }^{\circ} \mathrm{C}$ before being warmed to $0{ }^{\circ} \mathrm{C}$ and diluted with $\mathrm{Et}_{2} \mathrm{O}$. The reaction was quenched with sat. aq. $\mathrm{NaHCO}_{3}$, and the aqueous phase extracted twice with $\mathrm{Et}_{2} \mathrm{O}$. The combined organic fractions were washed with water and brine, then dried $\left(\mathrm{Na}_{2} \mathrm{SO}_{4}\right)$ and concentrated. Purification by flash column chromatography (5\% EtOAc/petrol) gave TMS ether 13 (206 mg, 67\%) as a colourless oil. $[\alpha]_{D}^{19}=-3.1\left(c 1.1, \mathrm{CH}_{2} \mathrm{Cl}_{2}\right) ;{ }^{1} \mathrm{H}$ NMR $\delta(600 \mathrm{MHz}) 0.17(\mathrm{~s}, 9 \mathrm{H}), 0.92(\mathrm{t}, J=7.4$ $\mathrm{Hz}), 1.38(\mathrm{~m}, 2 \mathrm{H}), 1.43(\mathrm{~s}, 9 \mathrm{H}), 1.43(\mathrm{~s}, 9 \mathrm{H}), 1.64(\mathrm{~m}, 2 \mathrm{H}), 2.27$ (dddt, $J=14.0,6.1,3.0,1.5 \mathrm{~Hz}, 1 \mathrm{H})$, 2.46 (dddt, $J=14.0,12.0,7.5,1.1 \mathrm{~Hz}, 1 \mathrm{H}), 2.66$ (dd, $J=12.0,2.9 \mathrm{~Hz}, 1 \mathrm{H}), 2.67$ (ABq, $J=15.9 \mathrm{~Hz}$, 1H), 2.99 (ABq, $J=15.9 \mathrm{~Hz}, 1 \mathrm{H}), 4.07(\mathrm{dt}, J=10.8,6.8 \mathrm{~Hz}, 1 \mathrm{H}), 4.23$ (dt, $J=10.8,7.0 \mathrm{~Hz}), 5.00$ $(\mathrm{dq}, J=10.2,1.4 \mathrm{~Hz}, 1 \mathrm{H}), 5.06$ (dq, $J=17.1,1.6 \mathrm{~Hz}, 1 \mathrm{H}), 5.69$ (dddd, $J=17.2,10.0,7.3,6.1 \mathrm{~Hz}$, $1 \mathrm{H}) ;{ }^{13} \mathrm{C}$ NMR $\delta(150 \mathrm{MHz}) 2.58,13.8,19.3,28.3,28.3,30.6,32.2,43.3,55.3,65.5,79.0,80.8,81.2$, 116.9, 135.5, 169.2, 170.7, 173.0; HRMS (ESI) calculated for $\mathrm{C}_{24} \mathrm{H}_{44} \mathrm{NaO}_{7} \mathrm{Si}[\mathrm{M}+\mathrm{Na}]^{+} 495.2754$, found 495.2745 .

\section{Vinyl iodide 15}

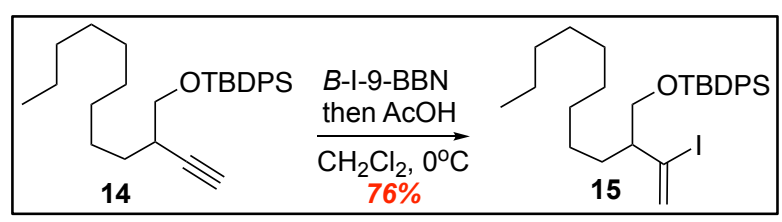

$B$-iodo-9-BBN (3.87 mL, $1 \mathrm{M}$ in hexanes, $3.87 \mathrm{mmol})$ was added to a solution of alkyne $\mathbf{1 4}^{3}$ (841 $\mathrm{mg}, 1.94 \mathrm{mmol})$ in $\mathrm{CH}_{2} \mathrm{Cl}_{2}(17 \mathrm{~mL})$ at $0{ }^{\circ} \mathrm{C}$, and the deep red solution was stirred for $3 \mathrm{~h}$. Glacial acetic 
acid $(1.85 \mathrm{~mL})$ was added, and the reaction mixture stirred for a further $1 \mathrm{~h}$. The mixture was quenched with water, the aqueous phase extracted with petrol, and the combined organic fractions washed with saturated $\mathrm{Na}_{2} \mathrm{~S}_{2} \mathrm{O}_{3}$, water and brine, dried $\left(\mathrm{Na}_{2} \mathrm{SO}_{4}\right)$ and concentrated. Purification by column chromatography (petrol as eluent) afforded vinyl iodide $15(830 \mathrm{mg}, 76 \%)$ as a colourless oil. $v_{\max }$ 2957, 2926, 2856, 1465, 1428, 1112, 824, 739, $701 \mathrm{~cm}^{-1} ;{ }^{1} \mathrm{H}$ NMR $\delta(600 \mathrm{MHz}) 0.88$ (t, $J=7.0 \mathrm{~Hz}$, 3H), 1.04 (s, 9H), 1.25 (br s, 16H), $1.84(\mathrm{~m}, 1 \mathrm{H}), 3.47$ (dd, $J=10.2,5.4 \mathrm{~Hz}, 1 \mathrm{H}), 3.52$ (dd, $J=10.2$, $7.81 \mathrm{~Hz}, 1 \mathrm{H}), 5.87(\mathrm{~d}, J=1.2 \mathrm{~Hz}, 1 \mathrm{H}), 6.20(\mathrm{~s}, 1 \mathrm{H}), 7.40(\mathrm{~m}, 5 \mathrm{H}), 7.68(\mathrm{~m}, 5 \mathrm{H}) ;{ }^{13} \mathrm{C}$ NMR $\delta(150$ MHz) 14.3, 19.5, 22.8, 26.7, 27.0, 29.5, 29.5 29.6, 29.7, 30.6, 32.0, 54.2, 66.5, 118.4, 127.1, 127.8, 129.7, 133.7, 133.9, 135.7, 135.9; HRMS (ESI) calculated for $\mathrm{C}_{29} \mathrm{H}_{44} \mathrm{IOSi}[\mathrm{M}+\mathrm{H}]^{+} 563.2206$, found 563.2197.

\section{Acetal 4}

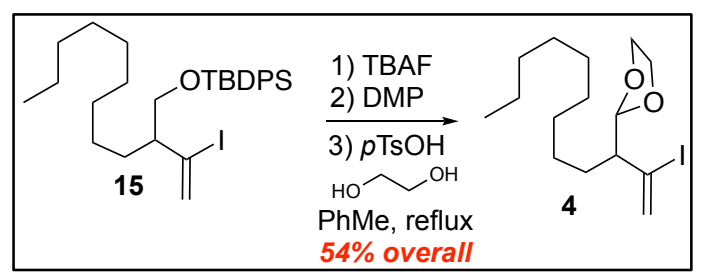

TBAF (10.5 mL, $1 \mathrm{M}$ in THF, $10.5 \mathrm{mmol}$ ) was added to a solution of vinyl iodide $\mathbf{1 5}$ (2.37 $\mathrm{g}, 4.21$ $\mathrm{mmol})$ in THF $(60 \mathrm{~mL})$ at $0{ }^{\circ} \mathrm{C}$ and the solution was then warmed to $\mathrm{rt}$ and stirred for $16 \mathrm{~h}$. The reaction mixture was quenched with water, the aqueous phase extracted with $\mathrm{Et}_{2} \mathrm{O}$, and the combined organic phases were washed with water and brine, dried $\left(\mathrm{Na}_{2} \mathrm{SO}_{4}\right)$ and concentrated. Purification by flash column chromatography (10\% EtOAc/petrol) afforded alcohol (1.21 g, 88\%) as a colourless oil. DMP (194 mg, $0.457 \mathrm{mmol}$ ) was added to a solution of alcohol (114 mg, $0.352 \mathrm{mmol})$ in $\mathrm{CH}_{2} \mathrm{Cl}_{2}(8.5$ $\mathrm{mL})$ at $0{ }^{\circ} \mathrm{C}$. Additional DMP ( $\left.2 \times 100 \mathrm{mg}\right)$ was added at $1 \mathrm{~h}$ intervals, and a drop of water with the second addition. The reaction mixture was stirred for $4 \mathrm{~h}$ at $\mathrm{rt}$, then diluted in hexane, quenched with solid $\mathrm{NaHCO}_{3}$, and the $\mathrm{CH}_{2} \mathrm{Cl}_{2}$ was evaporated. The suspension was cooled, filtered through Celite, and concentrated. The crude residue was dissolved in toluene (ca. $6 \mathrm{~mL}$ ), and to this $p$-TsOH monohydrate $(8.3 \mathrm{mg}, 0.044 \mathrm{mmol})$ and ethylene glycol $(0.25 \mathrm{~mL}, 4.4 \mathrm{mmol})$ were added. The reaction mixture was stirred at reflux in a Dean Stark apparatus for $4 \mathrm{~h}$, then cooled to rt, quenched with saturated $\mathrm{NaHCO}_{3}$ and extracted with ethyl acetate. The combined organic fractions were washed with water and brine, dried $\left(\mathrm{Na}_{2} \mathrm{SO}_{4}\right)$ and concentrated. Purification by flash column chromatography (2.5\% EtOAc/petrol) afforded acetal 4 (80 mg, 62\%) as a colourless oil. $v_{\max } 2922$, $2854,1614,1465,1393,1378,1145,1118,1037,943,895 \mathrm{~cm}^{-1} ;{ }^{1} \mathrm{H}$ NMR $\delta(400 \mathrm{MHz}) 0.87(\mathrm{t}, J=$ $7.0 \mathrm{~Hz}, 3 \mathrm{H}), 1.25$ (br s, 14H), 1.49-1.62 (m, 2H), 1.81 (ddd, $J=10.5,6.6,3.8 \mathrm{~Hz}, 1 \mathrm{H}), 3.86-4.01$ (m, $4 \mathrm{H}), 4.76(\mathrm{~d}, J=6.5 \mathrm{~Hz}, 1 \mathrm{H}), 5.94(\mathrm{~d}, \mathrm{~J}=1.3 \mathrm{~Hz}, 1 \mathrm{H}), 6.3(\mathrm{~d}, J=1.3 \mathrm{~Hz}, 1 \mathrm{H}){ }^{13} \mathrm{C} \mathrm{NMR} \delta(100 \mathrm{MHz})$ $14.3,22.8,26.5$, 29.5, 29.5, 29.6, 29.7, 32.0, 55.3, 65.1, 65.2, 105.9, 112.0, 112.7, 128.3; HRMS (ESI) calculated for $\mathrm{C}_{15} \mathrm{H}_{28} \mathrm{IO}_{2}[\mathrm{M}+\mathrm{H}]^{+} 367.1134$, found 367.1128 . 


\section{Enone 16}

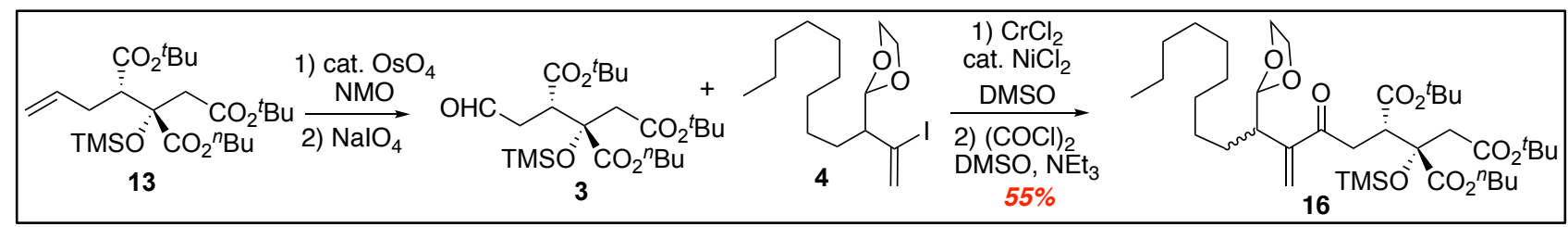

To a solution of alkene $13(67.1 \mathrm{mg}, 0.142 \mathrm{mmol})$ in 3:1 THF: $\mathrm{H}_{2} \mathrm{O}(5.1 \mathrm{~mL})$ at $\mathrm{rt}$ was added NMO (57 mg, $0.49 \mathrm{mmol})$ and $\mathrm{OsO}_{4}(0.36 \mathrm{M}$ in benzene, $34 \mu \mathrm{L}, 12 \mu \mathrm{mol})$, and the resulting solution was stirred for $2 \mathrm{~h} . \mathrm{NaIO}_{4}(108 \mathrm{mg}, 0.50 \mathrm{mmol})$ was added and the mixture was stirred for $16 \mathrm{~h}$, before being quenched with sat. aq. $\mathrm{Na}_{2} \mathrm{~S}_{2} \mathrm{O}_{3}$. The organic phase was washed with $\mathrm{H}_{2} \mathrm{O}$ and brine, dried $\left(\mathrm{Na}_{2} \mathrm{SO}_{4}\right)$ and concentrated. A portion $(71 \%)$ of the crude aldehyde $3(47 \mathrm{mg}, 0.099 \mathrm{mmol})$ and vinyl iodide 4 (133 mg, $0.36 \mathrm{mmol}$ ) were dried by azeotropic removal of water with toluene and the mixture was then dissolved in dry DMSO $(1.0 \mathrm{~mL})$. $\mathrm{NiCl}_{2}(1.84 \mathrm{mg}, 14.2 \mu \mathrm{mol})$ and $\mathrm{CrCl}_{2}(105 \mathrm{mg}, 0.85$ mmol - weighed out in glove box) were suspended in DMSO (1.0 mL) and stirred for $10 \mathrm{~min}$ at $\mathrm{rt}$, before dropwise addition of aldehyde/vinyl iodide solution. The reaction mixture was stirred at $\mathrm{rt}$ for 18 then heated to $35{ }^{\circ} \mathrm{C}$ for $5 \mathrm{~h}$, cooled and diluted with $\mathrm{H}_{2} \mathrm{O}$ and $\mathrm{Et}_{2} \mathrm{O}$. The aqueous phase was extracted with $\mathrm{Et}_{2} \mathrm{O}$, the combined extracts were washed with $\mathrm{H}_{2} \mathrm{O}$, brine, dried $\left(\mathrm{Na}_{2} \mathrm{O}_{4}\right)$ and concentrated. Purification by flash column chromatography (5\% EtOAc/petrol) afforded allylic alcohol as a mixture of diastereomers $(71.5 \mathrm{mg}, 63 \%)$ as a colourless oil. DMSO (35 $\mu \mathrm{L}, 0.49 \mathrm{mmol})$ was added to a solution of oxalyl chloride $(27 \mu \mathrm{L}, 0.31 \mathrm{mmol})$ in $\mathrm{CH}_{2} \mathrm{Cl}_{2}(1 \mathrm{~mL})$ cooled to $-78{ }^{\circ} \mathrm{C}$, and stirred for $30 \mathrm{~min}$. A solution of above alcohols (44.4 mg, $0.062 \mathrm{mmol})$ in $\mathrm{CH}_{2} \mathrm{Cl}_{2}(1 \mathrm{~mL})$ was added and the reaction mixture was stirred for $1 \mathrm{~h} . \mathrm{Et}_{3} \mathrm{~N}(86 \mu \mathrm{L}, 0.62 \mathrm{mmol})$ was added, and the mixture was warmed to $0{ }^{\circ} \mathrm{C}$ and stirred for $1 \mathrm{~h}$, then diluted with $\mathrm{Et}_{2} \mathrm{O}$ and water. The aqueous phase was extracted with $\mathrm{Et}_{2} \mathrm{O}$, and the combined organic fractions washed with water, then brine, dried and concentrated. Purification by flash column chromatography (5\% EtOAc/petrol) afforded enone 16 as a $1: 1$ mixture of diastereomers $(32.6 \mathrm{mg}, 87 \%, 55 \%$ overall from 13$)$ as a colourless oil. ${ }^{1} \mathrm{H}$ NMR $\delta(600 \mathrm{MHz}) 0.165(\mathrm{~s}, 9 \mathrm{H}), 0.169(\mathrm{~s}, 9 \mathrm{H}), 0.87(\mathrm{t}, J=6.9 \mathrm{~Hz}, 6 \mathrm{H}), 0.93$ (t, $J=7.2 \mathrm{~Hz}, 6 \mathrm{H})$, 1.21 (br s, 32H), $1.35(\mathrm{~m}, 4 \mathrm{H}), 1.41(\mathrm{~s}, 9 \mathrm{H}), 1.42(\mathrm{~s}, 9 \mathrm{H}), 1.43(\mathrm{~s}, 18 \mathrm{H}), 1.62(\mathrm{~m}, 4 \mathrm{H}), 2.50(\mathrm{dd}, J=$ 17.8, 2.7 Hz, 1H), $2.62(\mathrm{dd}, J=17.8,2.7 \mathrm{~Hz}, 1 \mathrm{H}),$,2.81 and $3.02(\mathrm{ABq}, J=16.4 \mathrm{~Hz}, 2 \mathrm{H}), 2.82$ and $3.02(\mathrm{ABq}, J=16.4 \mathrm{~Hz}, 2 \mathrm{H}), 2.96(\mathrm{~m}, 2 \mathrm{H}), 3.05(\mathrm{~m}, 2 \mathrm{H}), 3.10(\mathrm{dd}, J=4.2,2.7 \mathrm{~Hz}, 1 \mathrm{H}), 3.11$ (ddd, $J$ $=11.6,3.5,2.7 \mathrm{~Hz}, 2 \mathrm{H}), 3.76-3.90(\mathrm{~m}, 8 \mathrm{H}), 4.06(\mathrm{~m}, 2 \mathrm{H}), 4.20(\mathrm{~m}, 2 \mathrm{H}), 4.80(\mathrm{~d}, J=5.3 \mathrm{~Hz}, 1 \mathrm{H})$, $4.86(\mathrm{~d}, J=5.1 \mathrm{~Hz}, 1 \mathrm{H}), 5.82(\mathrm{~s}, 1 \mathrm{H}), 5.83(\mathrm{~s}, 1 \mathrm{H}), 6.17(\mathrm{~s}, 1 \mathrm{H}), 6.18(\mathrm{~s}, 1 \mathrm{H}){ }^{13} \mathrm{C} \mathrm{NMR} \delta(150 \mathrm{MHz})$ informative resonances: 78.67, 78.70, 80.90, 80.91, 81.1, 83.1, 106.1, 106.4, 106.4, 125.06, 125.07, $125.8,147.5,147.7,169.29,169.31,169.96,169.97,172.68,172.70,199.4,199.6$; HRMS (ESI) calculated for $\mathrm{C}_{38} \mathrm{H}_{69} \mathrm{O}_{10} \mathrm{Si}[\mathrm{M}+\mathrm{H}]^{+}$713.4660, found 713.4658. 


\section{Trachyspic acid di-tert-butyl-19-n-butyl ester 17}

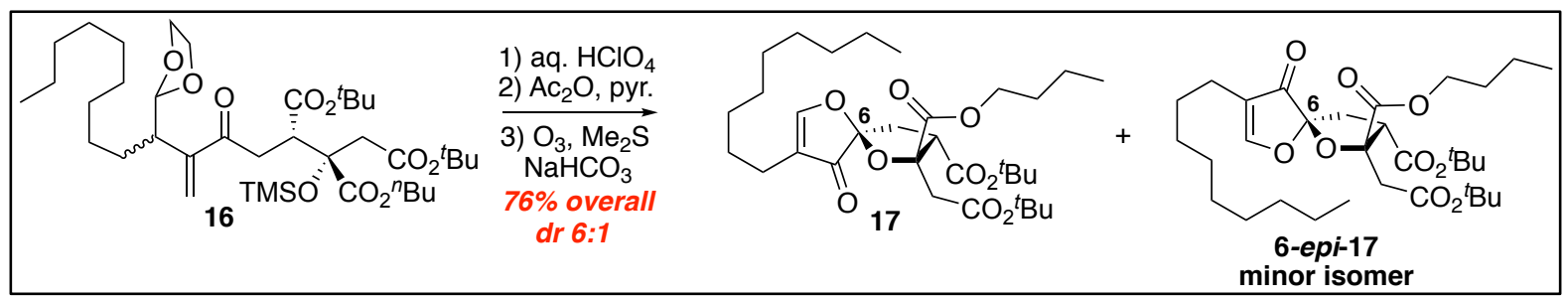

To a solution of enone $\mathbf{1 6}(36.1 \mathrm{mg}, 0.051 \mathrm{mmol})$ in THF $(1.3 \mathrm{~mL})$ at $0{ }^{\circ} \mathrm{C}$ was added $3 \mathrm{M} \mathrm{HClO}_{4}$ $(1.0 \mathrm{~mL})$. The solution was warmed to $\mathrm{rt}$, and stirred for $6 \mathrm{~h}$. The reaction mixture was quenched with sat. aqueous $\mathrm{NaHCO}_{3}$, and the aqueous phase extracted with $\mathrm{Et}_{2} \mathrm{O}$. The combined extracts were washed with water, brine, dried $\left(\mathrm{Na}_{2} \mathrm{SO}_{4}\right)$ and concentrated. The crude residue was dissolved in pyridine $(1.7 \mathrm{~mL})$, and to this was added DMAP $(0.65 \mathrm{mg}, 5.3 \mu \mathrm{mol})$ and acetic anhydride $(50 \mu \mathrm{L}$, $0.53 \mathrm{mmol}$ ). The mixture was stirred at $\mathrm{rt}$ for $16 \mathrm{~h}$, then diluted with $\mathrm{H}_{2} \mathrm{O}$ and $\mathrm{Et}_{2} \mathrm{O}$. The aqueous phase was extracted with $\mathrm{Et}_{2} \mathrm{O}$, and the combined organic extracts were washed with aqueous $\mathrm{CuSO}_{4}$, water, brine, then dried and concentrated. The crude residue (24 mg) was dissolved in $\mathrm{CH}_{2} \mathrm{Cl}_{2}(3.4$ $\mathrm{mL})$ and $\mathrm{MeOH}(0.34 \mathrm{~mL})$ and cooled to $-78{ }^{\circ} \mathrm{C}$. Ozone gas was bubbled through until a pale blue colour persisted, and dimethyl sulphide $(40 \mu \mathrm{L}, 0.54 \mathrm{mmol})$ and $\mathrm{NaHCO}_{3}(40 \mathrm{mg}, 0.48 \mathrm{mmol})$ were added and the mixture was stirred at $\mathrm{rt}$ for $16 \mathrm{~h}$. The reaction mixture was diluted with $\mathrm{H}_{2} \mathrm{O}$ and ether, and the aqueous phase extracted with ether. The combined organic extracts were washed with water, brine, dried $\left(\mathrm{Na}_{2} \mathrm{SO}_{4}\right)$ and concentrated. Purification by flash column chromatography (5\%

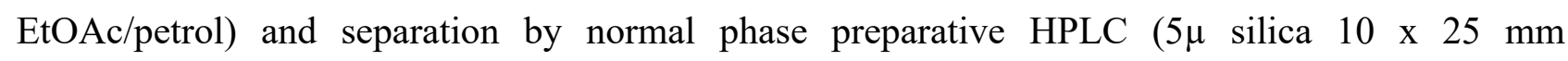
Phenomonex $^{\circledR}$ column, 10\% EtOAc/petrol as eluent, flow rate $2 \mathrm{mLmin}^{-1}$ ) afforded the minor spiroketal $\left(\mathrm{R}_{t}=17.50 \mathrm{~min}, 3.2 \mathrm{mg}, 11 \%\right)$ and the major spiroketal $17\left(\mathrm{R}_{t}=18.75 \mathrm{~min}, 19.1 \mathrm{mg}, 65 \%\right.$, dr 6:1) as a thin film.

Data for major isomer 17: $[\alpha]_{D}^{22}=+3.6\left(c 0.18, \mathrm{CH}_{2} \mathrm{Cl}_{2}\right) ;{ }^{1} \mathrm{H} \mathrm{NMR} \delta(600 \mathrm{MHz}) 0.88(\mathrm{t}, J=7.1 \mathrm{~Hz}$, $3 \mathrm{H}), 0.93$ (t, J=7.4 Hz, 3H), 1.25 (br s, 12H), 1.40 (m, 2H), 1.41 (s, 9H), 1.44 (m, 2H) 1.47 (s, 9H), $1.67(\mathrm{~m}, 2 \mathrm{H}), 2.10(\mathrm{dt}, J=7.7,0.8 \mathrm{~Hz}, 2 \mathrm{H}), 2.26(\mathrm{dd}, J=13.3,7.1 \mathrm{~Hz}, 1 \mathrm{H}), 2.65(\mathrm{dd}, J=12.9,12.9$ $\mathrm{Hz}, 1 \mathrm{H}), 2.92$ and $3.00(\mathrm{ABq}, J=16.6 \mathrm{~Hz}, 2 \mathrm{H}), 3.61(\mathrm{dd}, J=12.5,7.1 \mathrm{~Hz}, 1 \mathrm{H}), 4.16(\mathrm{dt}, J=10.8$, $6.6 \mathrm{~Hz}), 4.30(\mathrm{dt}, J=10.7,6.8 \mathrm{~Hz}, 1 \mathrm{H}), 7.84\left(\mathrm{t},{ }^{4} J=1.0 \mathrm{~Hz}, 1 \mathrm{H}\right) ;{ }^{13} \mathrm{C} \mathrm{NMR} \delta(150 \mathrm{MHz}) 13.8,14.3$, 19.2, 21.3, 22.8, 28.0, 28.1, 28.2, 29.4, 29.6, 30.7, 32.0, 38.2, 39.8, 49.8, 65.9, 81.5, 82.4, 87.4, 108.3, 118.3, 168.2, 168.5, 170.8, 172.3, 198.1; HRMS (ESI) calculated for $\mathrm{C}_{32} \mathrm{H}_{53} \mathrm{O}_{9}[\mathrm{M}+\mathrm{H}]^{+} 581.3690$, found 581.3683 .

Data for minor isomer 6-epi-17: $[\alpha]_{D}^{20}=-7.8\left(c 0.1, \mathrm{CH}_{2} \mathrm{Cl}_{2}\right) ;{ }^{1} \mathrm{H}$ NMR $\delta(600 \mathrm{MHz}) 0.88(\mathrm{t}, J$ $=7.1 \mathrm{~Hz}, 3 \mathrm{H}), 0.94(\mathrm{t}, J=7.4 \mathrm{~Hz}, 3 \mathrm{H}), 1.25$ (br s, 14H), $1.40(\mathrm{~m}, 2 \mathrm{H}), 1.41(\mathrm{~s}, 9 \mathrm{H}), 1.44(\mathrm{~m}, 2 \mathrm{H}) 1.48$ (s, 9H), $1.69(\mathrm{~m}, 2 \mathrm{H}), 2.08(\mathrm{dt}, J=7.8,0.8 \mathrm{~Hz}, 1 \mathrm{H}), 2.54(\mathrm{dd}, J=14.0,5.7 \mathrm{~Hz}, 1 \mathrm{H}), 2.65(\mathrm{dd}, J=$ 14.0, 9.2 Hz, 1H), $3.07 \& 3.17(\mathrm{ABq}, J=16.7 \mathrm{~Hz}, 2 \mathrm{H}), 3.69(\mathrm{dd}, J=9.2,5.7 \mathrm{~Hz}, 1 \mathrm{H}), 4.19(\mathrm{dt}, J=$ 
10.7, $6.7 \mathrm{~Hz}, 1 \mathrm{H}), 4.26(\mathrm{dt}, J=10.7,6.7 \mathrm{~Hz}, 1 \mathrm{H}), 7.87\left(\mathrm{t},{ }^{4} J=0.9 \mathrm{~Hz}, 1 \mathrm{H}\right) ;{ }^{13} \mathrm{C} \mathrm{NMR} \delta(150 \mathrm{MHz})$ 13.9, 14.3, 19.2, 21.2, 22.8, 28.0, 28.1, 28.2, 29.4, 29.6, 29.9, 30.6, 31.1, 32.0, 37.5, 40.1, 50.0, 66.0, 81.6, 82.3, 88.2, 108.3, 117.7, 168.4, 169.4, 169.8, 172.5, 199.6; HRMS (ESI) calculated for $\mathrm{C}_{32} \mathrm{H}-$ ${ }_{53} \mathrm{O}_{9}[\mathrm{M}+\mathrm{H}]^{+}$581.3690, found 581.3683.

\section{Trachyspic acid 19-n-butyl ester (1)}

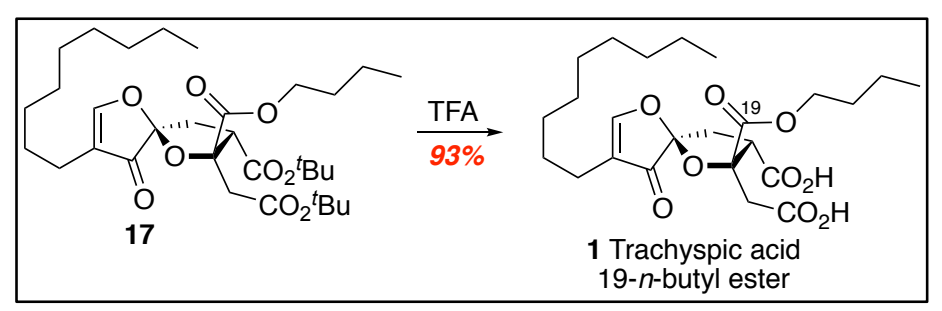

To a solution of triester $17(19.1 \mathrm{mg}, 32.9 \mu \mathrm{mol})$ in $\mathrm{CH}_{2} \mathrm{Cl}_{2}(3.0 \mathrm{~mL})$ at $0{ }^{\circ} \mathrm{C}$ was added trifluoroacetic acid $(446 \mu \mathrm{L})$. The reaction mixture was allowed to warm to $\mathrm{rt}$ and stirred for $40 \mathrm{~h}$, then concentrated by azeotropic removal of solvent with toluene. Purification by flash column chromatography (40:60:1 EtOAc/petrol/AcOH) afforded trachyspic acid 19-n-butyl ester (1) (14.4 mg, 93\%) as a thin film. $[\alpha]_{D}^{21}=+9.5\left(c 0.1, \mathrm{CHCl}_{3}\right) ;$ lit. $^{4}[\alpha]_{D}^{26}=+6.0\left(c 0.1, \mathrm{CHCl}_{3}\right) ;{ }^{1} \mathrm{H} \mathrm{NMR} \delta(600 \mathrm{MHz}) 0.88(\mathrm{t}, J=$ $7.0 \mathrm{~Hz}, 3 \mathrm{H}$ ), 0.92 (t, $J=7.4 \mathrm{~Hz}, 3 \mathrm{H}), 1.25$ (br s, 12H), 1.38 (app. sextet, $J=7.3 \mathrm{~Hz}, 2 \mathrm{H}), 1.44$ (m, 2H), $1.65(\mathrm{~m}, 2 \mathrm{H}), 2.10(\mathrm{t}, J=7.7 \mathrm{~Hz}, 2 \mathrm{H}), 2.35(\mathrm{dd}, J=13.1,7.0 \mathrm{~Hz}, 1 \mathrm{H}), 2.68(\mathrm{t}, J=13.3 \mathrm{~Hz}, 1 \mathrm{H})$, $3.24 \& 3.38(\mathrm{ABq}, J=17.6 \mathrm{~Hz}, 2 \mathrm{H}), 4.21(\mathrm{dt}, J=10.8,6.5 \mathrm{~Hz}, 1 \mathrm{H}), 4.26(\mathrm{dt}, J=10.8,6.6 \mathrm{~Hz}, 1 \mathrm{H})$, $4.36(\mathrm{dd}, J=13.0,6.7 \mathrm{~Hz}, 1 \mathrm{H}), 7.85(\mathrm{~s}, 1 \mathrm{H}) ;{ }^{13} \mathrm{C} \mathrm{NMR} \delta(150 \mathrm{MHz}) 13.7,14.3,19.1,21.3,22.8$, 28.0, 29.41, 29.41, 29.42, 29.6, 30.4, 32.0, 38.4, 38.5, 45.8, 66.7, 88.0, 107.7, 118.6, 168.4, 172.5, 176.1, 176.9, 197.6; HRMS (ESI) calculated for $\mathrm{C}_{24} \mathrm{H}_{37} \mathrm{O}_{9}[\mathrm{M}+\mathrm{H}]^{+} 469.2438$, found 469.2435. 


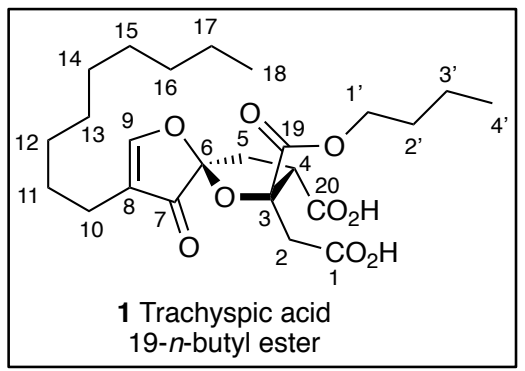

\begin{tabular}{|c|c|c|c|c|}
\hline Position & $\begin{array}{c}\text { Natural } 1^{4} \\
\delta_{\mathrm{H}}, \text { mult., } J(\mathrm{~Hz})\end{array}$ & $\begin{array}{c}\text { Synthetic } 1 \\
\delta_{\mathrm{H}}, \text { mult., } J(\mathrm{~Hz})\end{array}$ & $\begin{array}{c}\text { Natural } 1^{4} \\
\delta_{C} \\
\end{array}$ & $\begin{array}{c}\text { Synthetic } 1 \\
\delta_{\mathrm{C}} \\
\end{array}$ \\
\hline 1 & - & - & 175.9 & 176.1 \\
\hline $2 a$ & $3.23, \mathrm{~d}, 17.4$ & 3.24, ABq, 17.6 & 38.6 & 38.5 \\
\hline $2 b$ & $3.37, \mathrm{~d}, 17.4$ & $3.38, \mathrm{ABq}, 17.6$ & - & - \\
\hline 3 & - & - & 87.8 & 88.0 \\
\hline 4 & $4.34, \mathrm{dd}, 12.8,6.9$ & $4.36, \mathrm{dd}, 13.0,6.7$ & 45.6 & 45.8 \\
\hline 5a & $2.33, \mathrm{dd}, 12.8,6.9$ & $2.35, \mathrm{dd}, 13.1,7.0$ & 38.2 & 38.4 \\
\hline $5 \mathbf{b}$ & $2.66, \mathrm{dd}, 12.8,12.8$ & 2.68, app. t, 13.3 & - & - \\
\hline 6 & - & - & 107.6 & 107.7 \\
\hline 7 & - & - & 197.5 & 197.6 \\
\hline 8 & - & - & 118.4 & 118.6 \\
\hline 9 & $7.83, \mathrm{~s}$ & $7.85, \mathrm{~s}$ & 172.4 & 172.5 \\
\hline 10 & $2.08, t, 7.3$ & $2.10, \mathrm{t} 7.7$ & 21.0 & 21.3 \\
\hline 11 & $1.42,2 \mathrm{H}, \mathrm{m}$ & $1.44, \mathrm{~m}$ & 27.8 & 28.0 \\
\hline 12 & 1.23, br s & 1.25 , brs & 29.2 & 29.4 \\
\hline 13 & 1.23 & 1.25 & 29.2 & 29.4 \\
\hline 14 & 1.23 & 1.25 & 29.2 & 29.4 \\
\hline 15 & 1.23 & 1.25 & 29.4 & 29.6 \\
\hline 16 & 1.23 & 1.25 & 31.8 & 32.0 \\
\hline 17 & 1.23 & 1.25 & 22.6 & 22.8 \\
\hline 18 & $0.85, \mathrm{t}, 6.9$ & $0.88, \mathrm{t}, 7.0$ & 14.0 & 14.3 \\
\hline 19 & - & - & 168.3 & 168.4 \\
\hline 20 & - & - & 176.6 & 176.9 \\
\hline 1 ' & $4.21, \mathrm{~m}$ & $4.21, \mathrm{dt}, 10.8,6.5$ & 66.5 & 66.7 \\
\hline $2 '$ & $1.62, \mathrm{~m}$ & $1.65, \mathrm{~m}$ & 30.2 & 30.4 \\
\hline 3 & 1.35 , sextet, 7.3 & 1.38 , sextet, 7.3 & 18.9 & 19.1 \\
\hline $4 '$ & $0.89, \mathrm{t}, 7.3$ & $0.92, t, 7.4$ & 13.5 & 13.7 \\
\hline
\end{tabular}

Table 1: ${ }^{1} \mathrm{H}$ and ${ }^{13} \mathrm{C}$ NMR chemical shift data for natural ${ }^{4}$ trachyspic acid 19-butyl ester A (1) (500 and $\left.125 \mathrm{MHz}, \mathrm{CDCl}_{3}\right)$ and synthetic $1\left(600\right.$ and $\left.151 \mathrm{MHz}, \mathrm{CDCl}_{3}\right)$. 


\section{References}

(1) Hazarika, H.; Neog, K.; Sharma, A.; Das, B.; Gogoi, P. J. Org. Chem. 2019, 84, 5846-5854.

(2) Atkin, L.; Chen, Z.; Robertson, A.; Sturgess, D.; White, J. M.; Rizzacasa, M. A. Org. Lett. 2018, 20, 4255-4258.

(3) Zammit, S.; Ferro, V.; Hammond, E.; Rizzacasa, M. Org. Biomol. Chem. 2007, 5, 28262834.

(4) Nogawa, T.; Ogita, N.; Futamura, Y.; Negishi, S.; Watanabe, N.; Osada, H. J. Antibiot. 2017, 70, 705-707. 


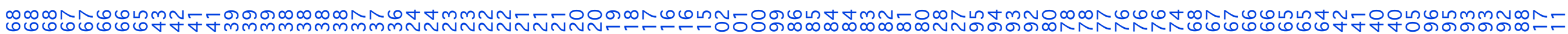
mm- - - - -

${ }^{1} \mathrm{H}$ NMR spectrum (600 $\mathrm{MHz} \mathrm{CDCl}_{3}$ )
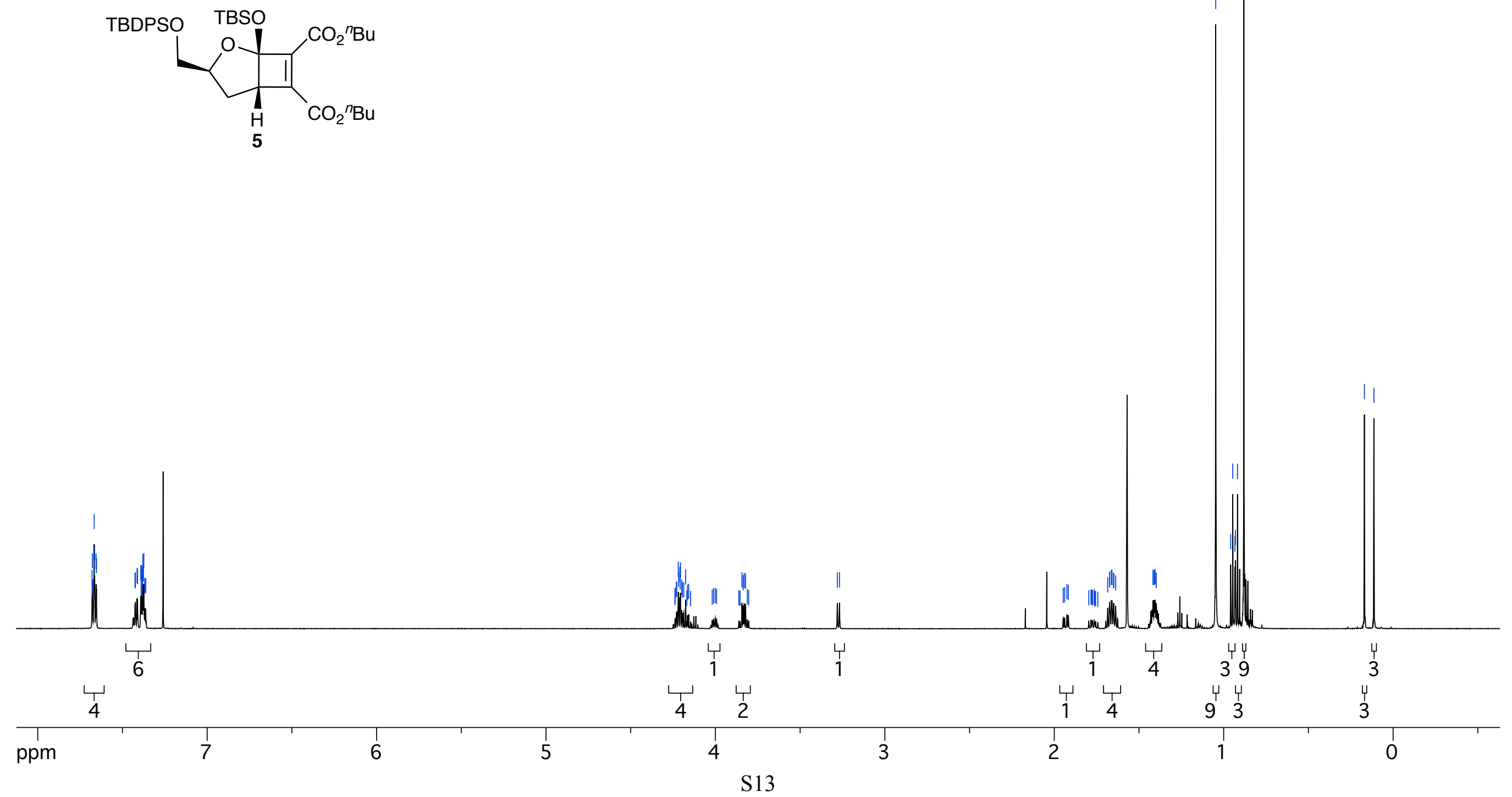


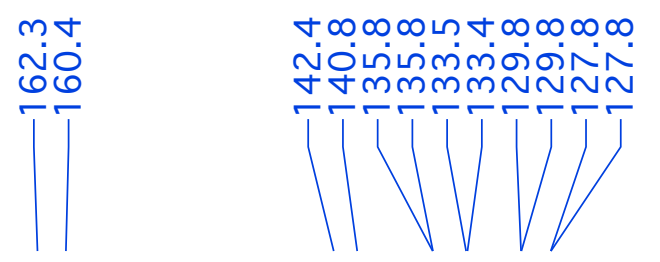

${ }^{13} \mathrm{C}$ NMR spectrum $\left(151 \mathrm{MHz}, \mathrm{CDCl}_{3}\right.$ )
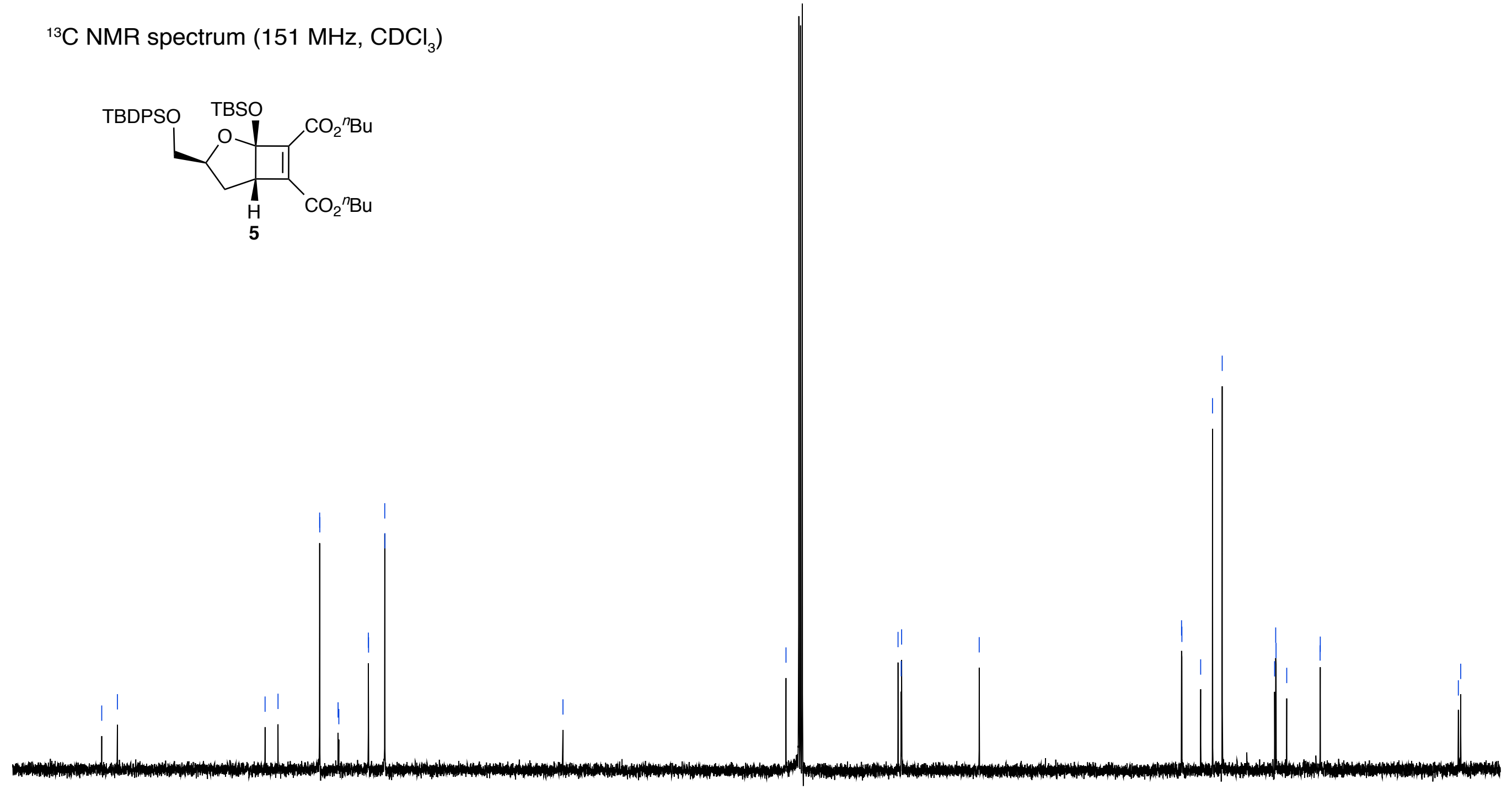


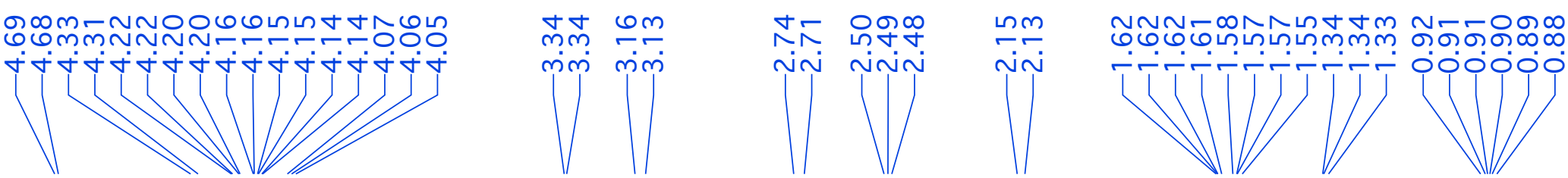

${ }^{1} \mathrm{H}$ NMR spectrum $\left(600 \mathrm{MHz}, \mathrm{CDCl}_{3}\right.$ )
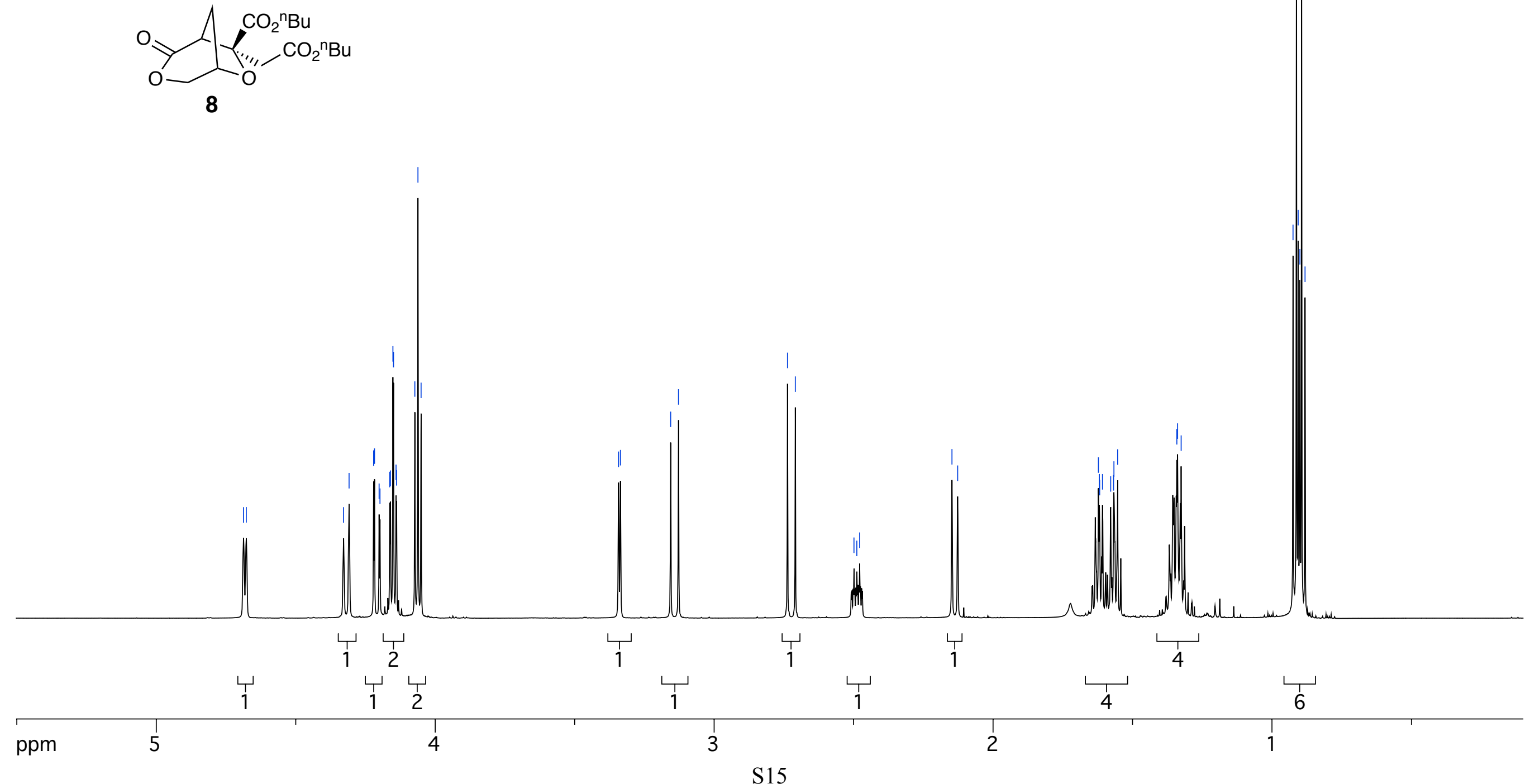
${ }^{13} \mathrm{C}$ NMR spectrum (151 $\mathrm{MHz}, \mathrm{CDCl}_{3}$ )
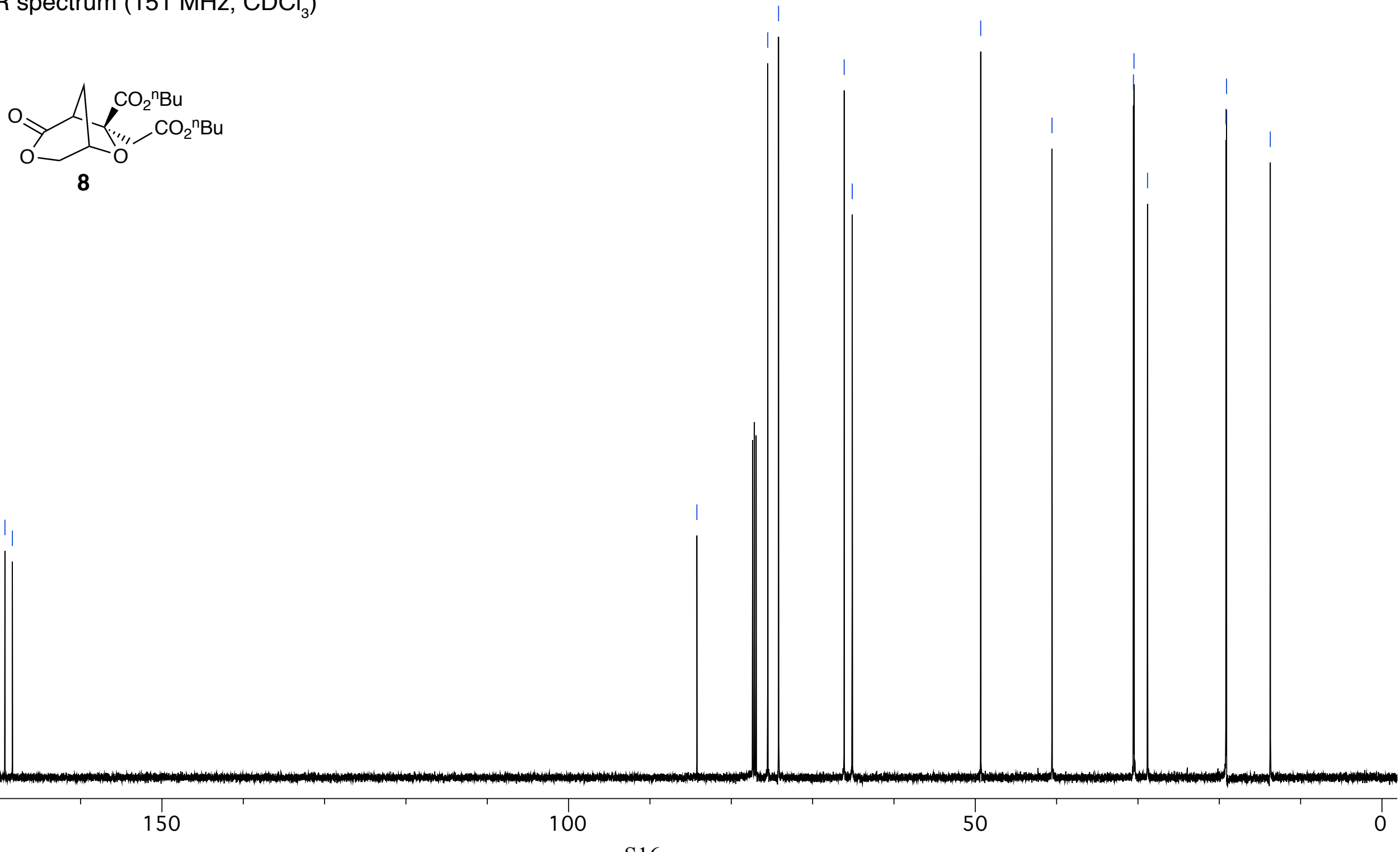


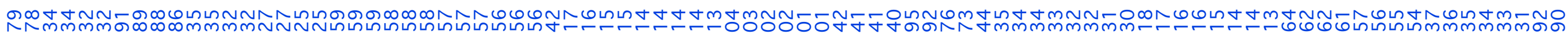

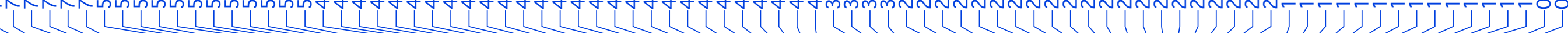

${ }^{1} \mathrm{H}$ NMR spectrum (600 MHz, $\mathrm{CDCl}_{3}$ )
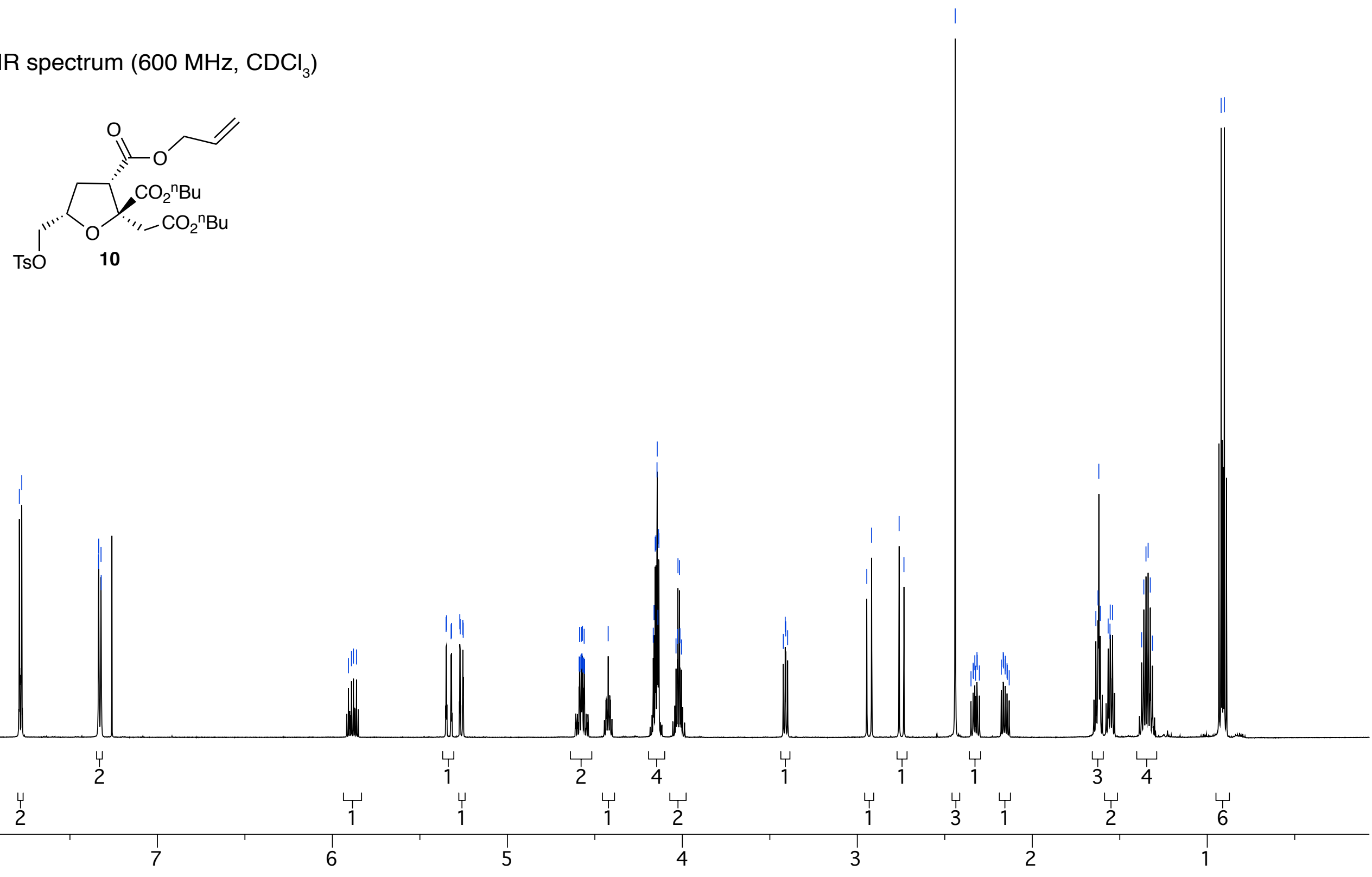

ppm 8

7 


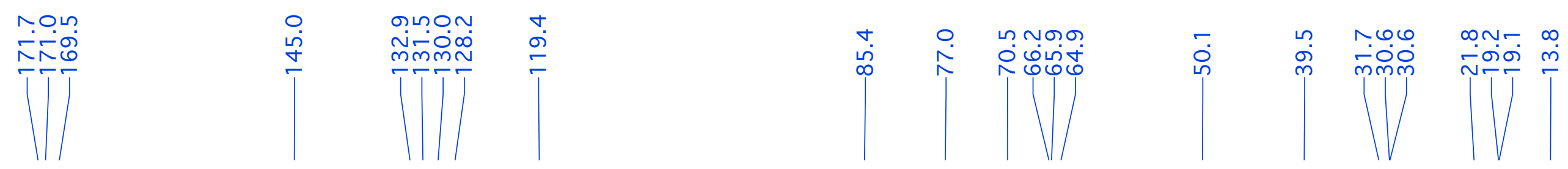

${ }^{13} \mathrm{C}$ NMR spectrum (151 MHz, $\mathrm{CDCl}_{3}$ )

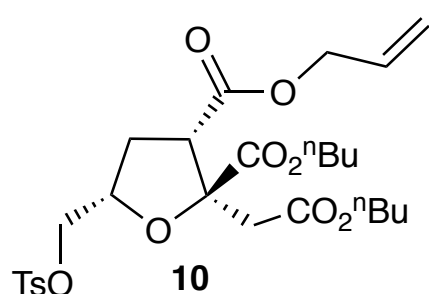


${ }^{1} \mathrm{H}$ NMR spectrum $\left(600 \mathrm{MHz}, \mathrm{CDCl}_{3}\right)$

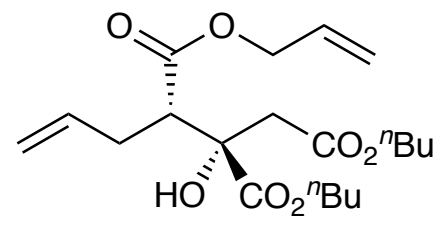

11

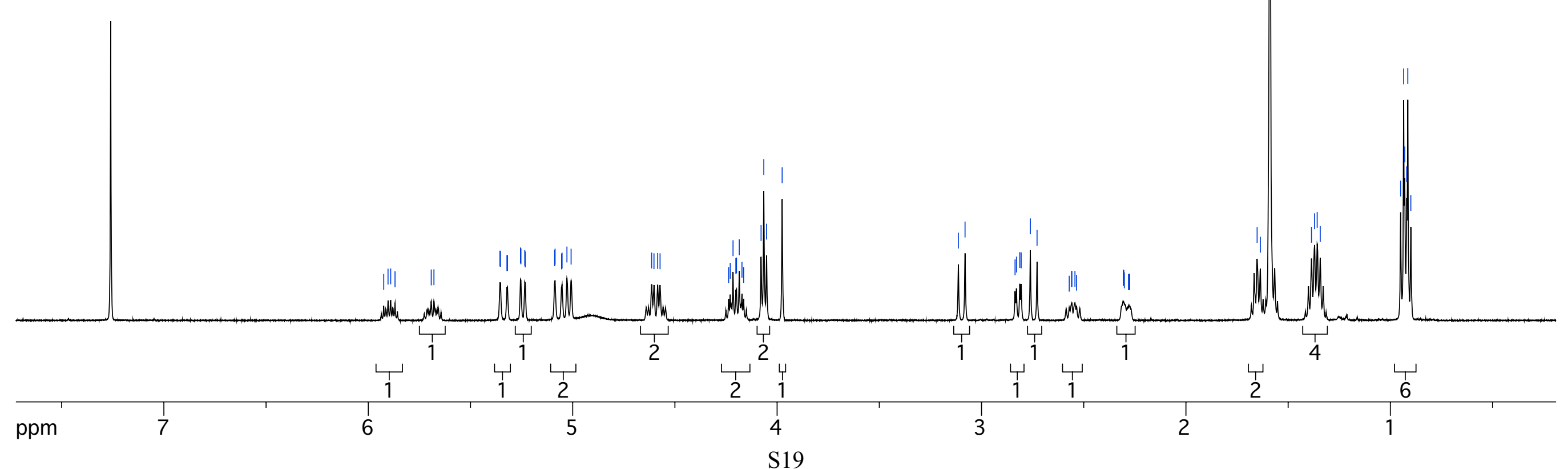




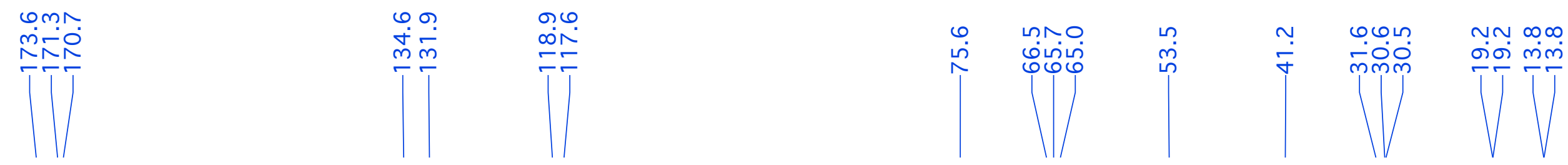

${ }^{13} \mathrm{C}$ NMR spectrum (151 MHz, $\mathrm{CDCl}_{3}$ )

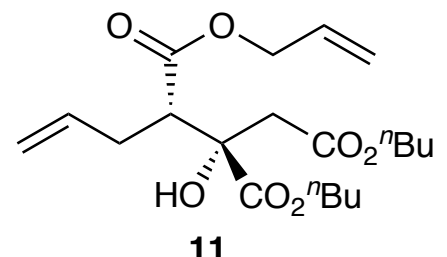

11

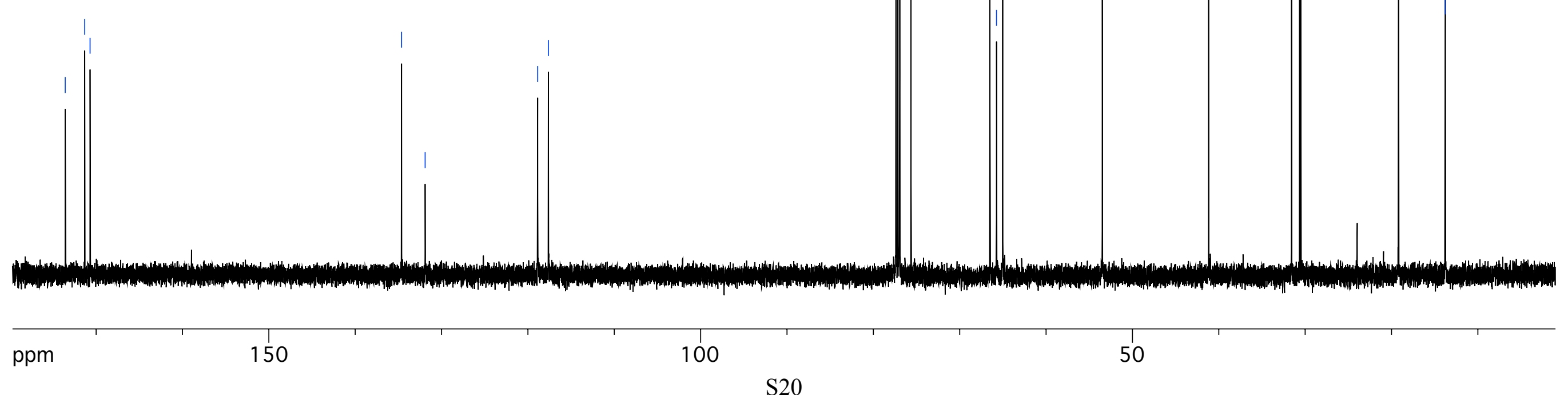


${ }^{1} \mathrm{H}$ NMR spectrum $\left(600 \mathrm{MHz}, \mathrm{CDCl}_{3}\right)$<smiles>C=CC[C@@H](C(=O)OCC)[C@](O)(CC(=O)OCCC)C(=O)OCCC</smiles>

12

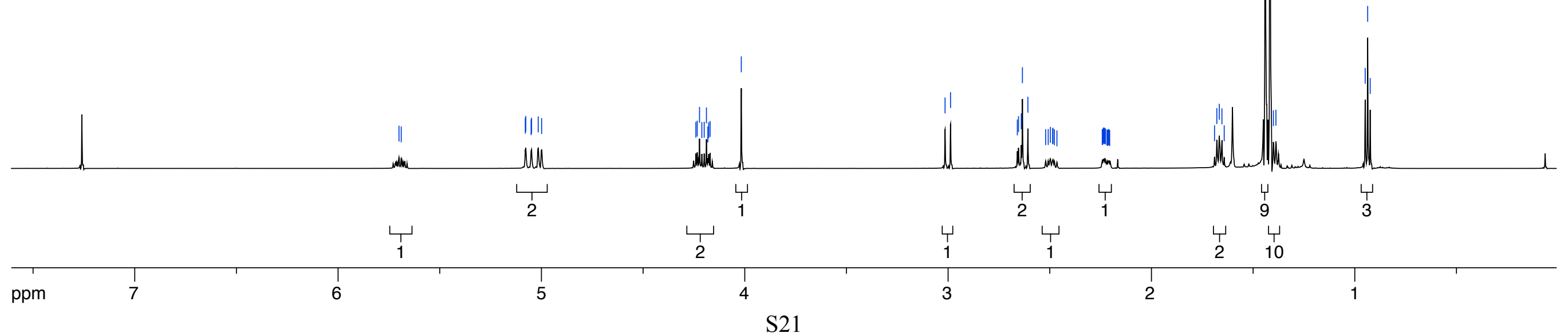




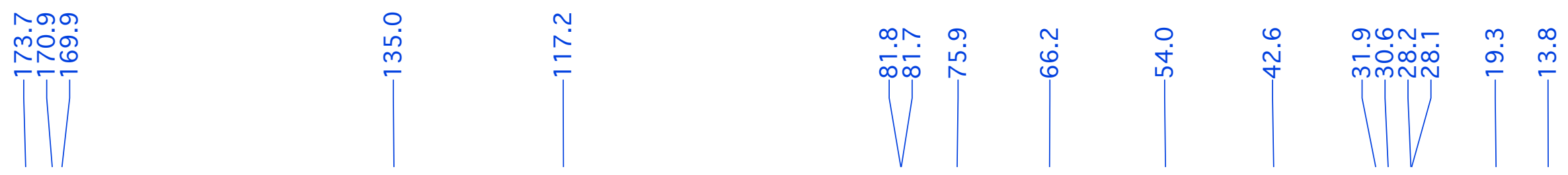

${ }^{13} \mathrm{C}$ NMR spectrum (151 MHz, $\mathrm{CDCl}_{3}$ )
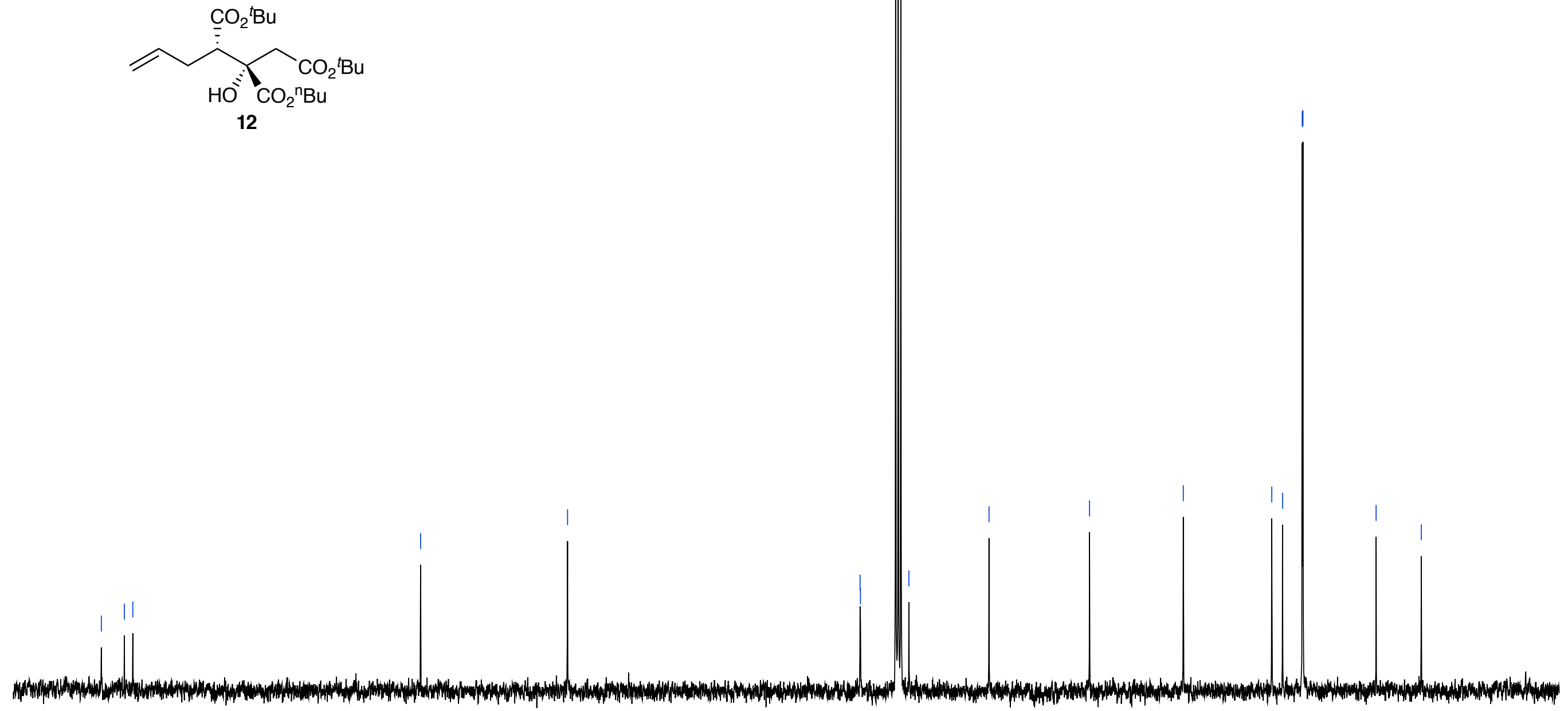


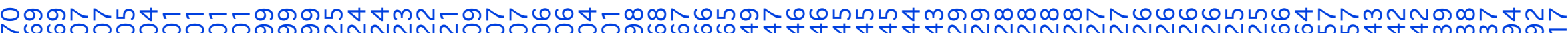

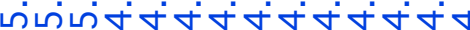

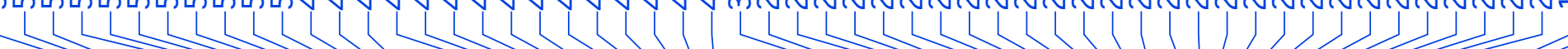

HMR spectrum $\left(600 \mathrm{MHz}, \mathrm{CDCl}_{3}\right)$

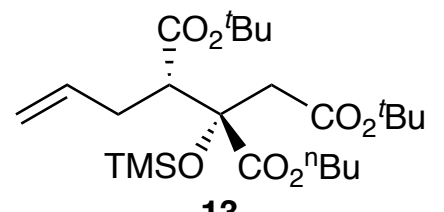

13

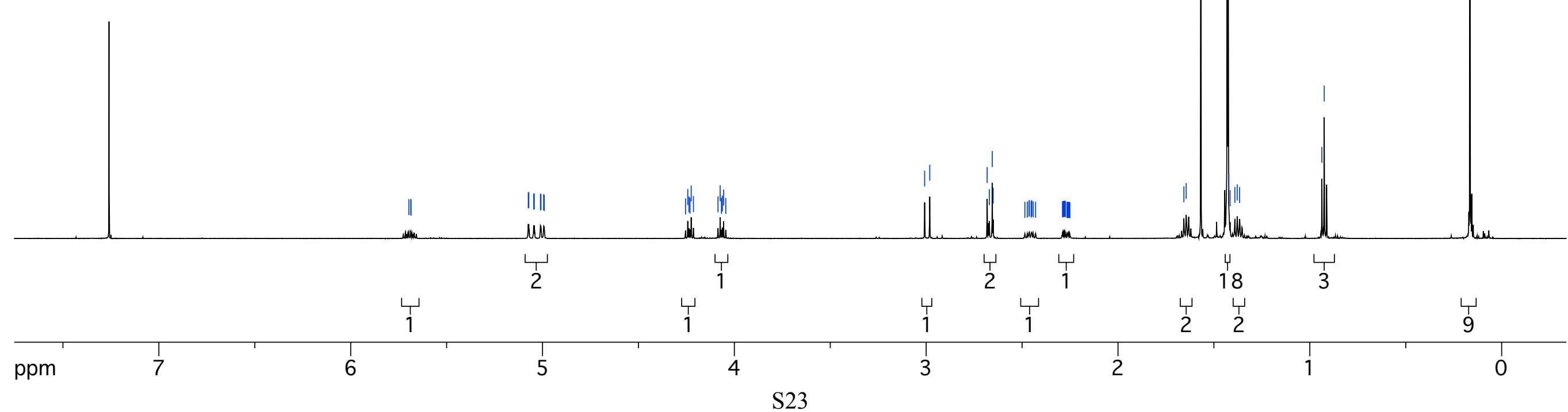




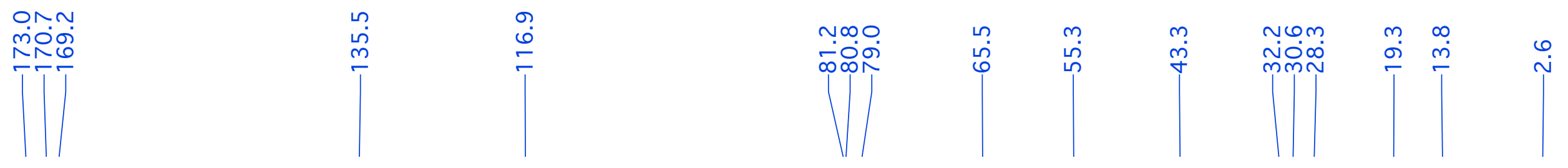

${ }^{13} \mathrm{C}$ NMR spectrum (151 MHz, $\mathrm{CDCl}_{3}$ )

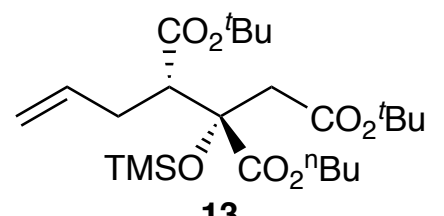

13 
${ }^{1} \mathrm{H}$ NMR spectrum $\left(600 \mathrm{MHz}, \mathrm{CDCl}_{3}\right)$
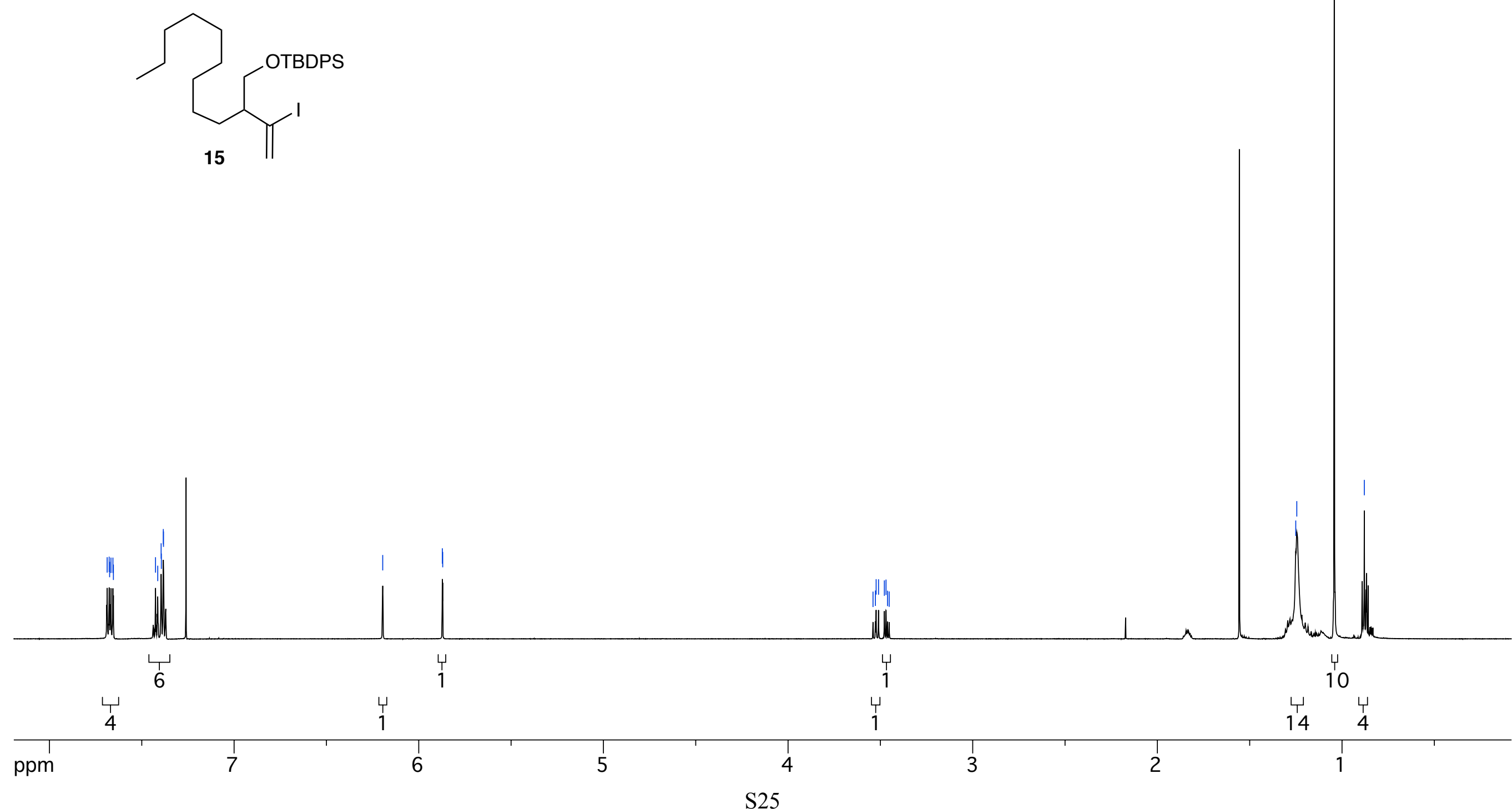
ดกดก ก⿻上.

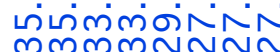

ーーーーーーーー

$\sqrt{1 / 1}|1|$

${ }^{13} \mathrm{C}$ NMR spectrum (150 $\mathrm{MHz}, \mathrm{CDCl}_{3}$ )
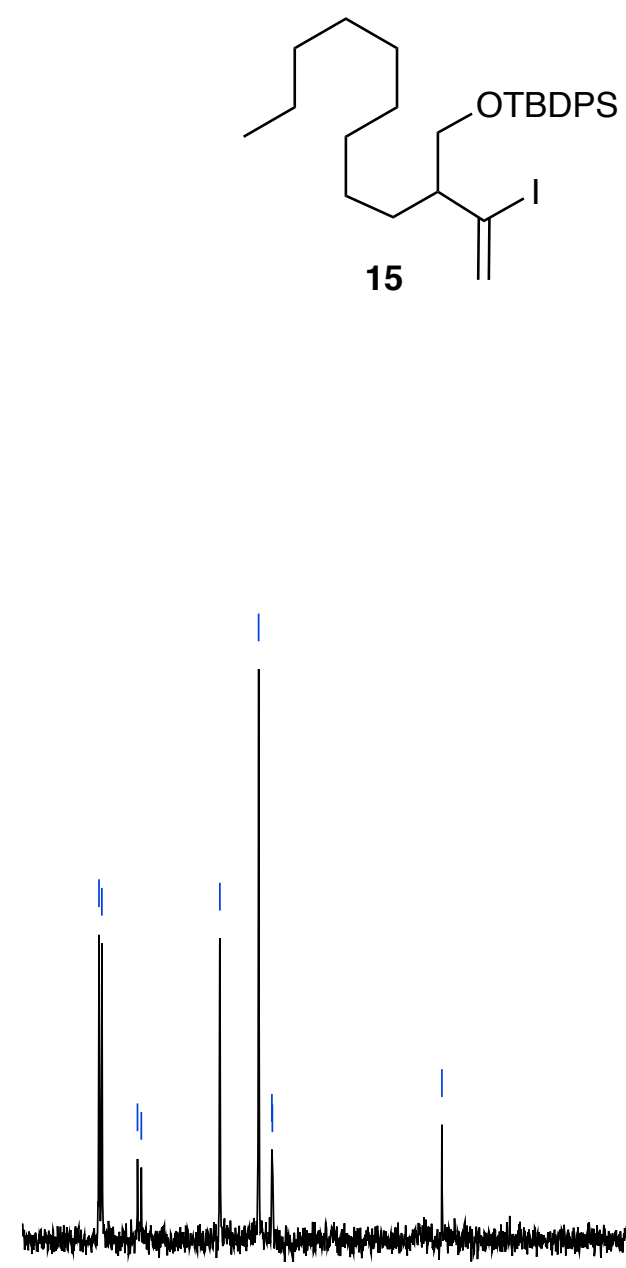

西

15 


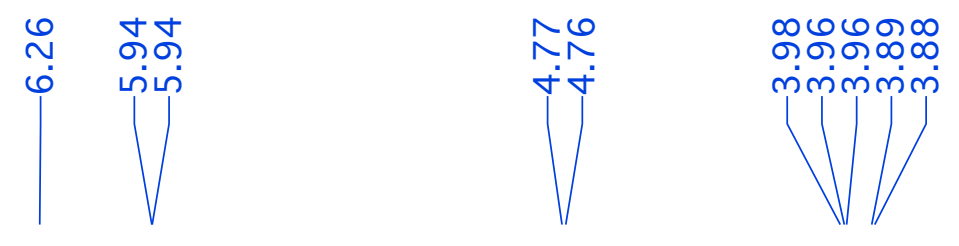

ก-

-ー - - - - -

${ }^{1} \mathrm{H}$ NMR spectrum (600 MHz, $\mathrm{CDCl}_{3}$ )
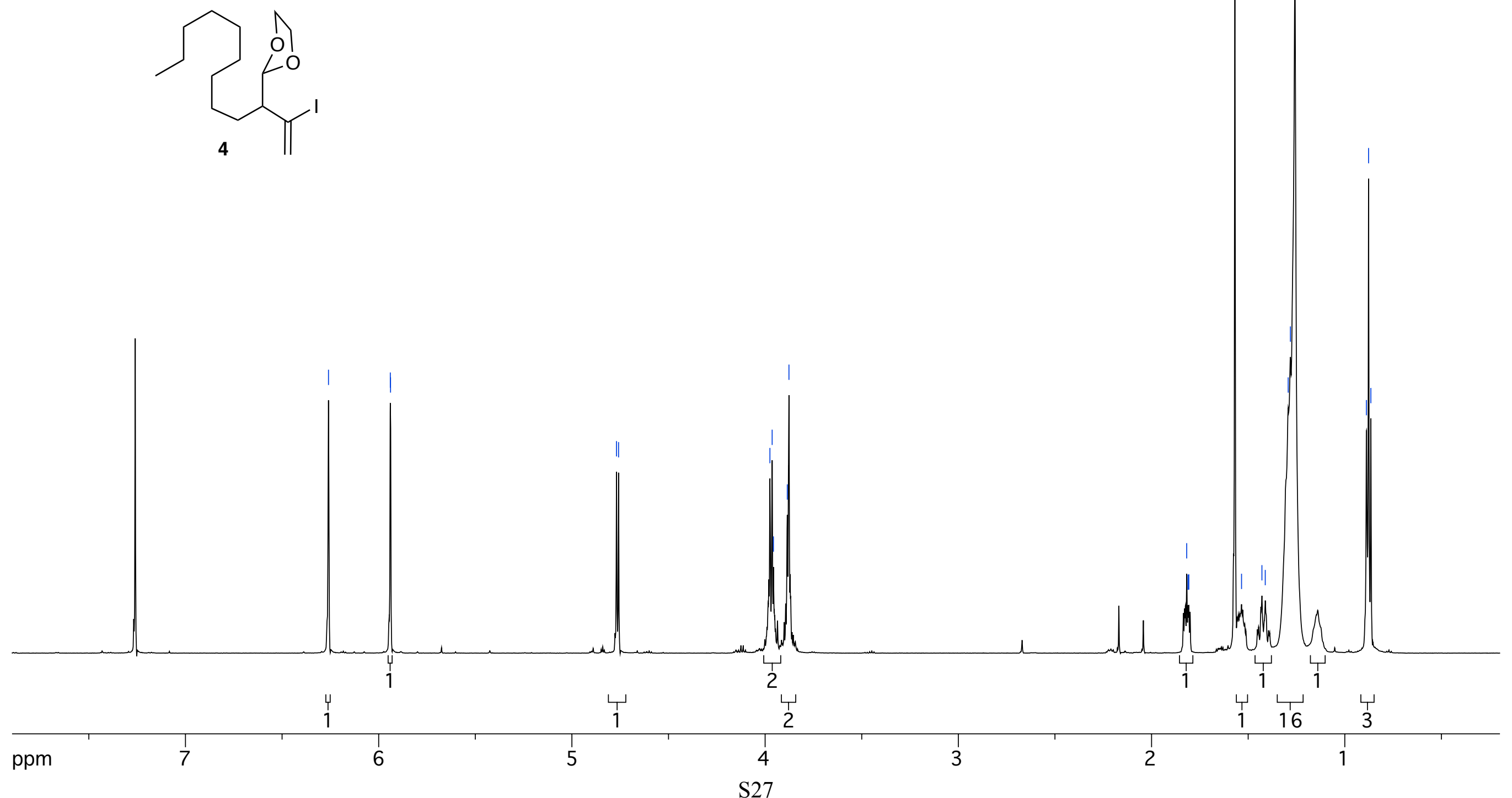

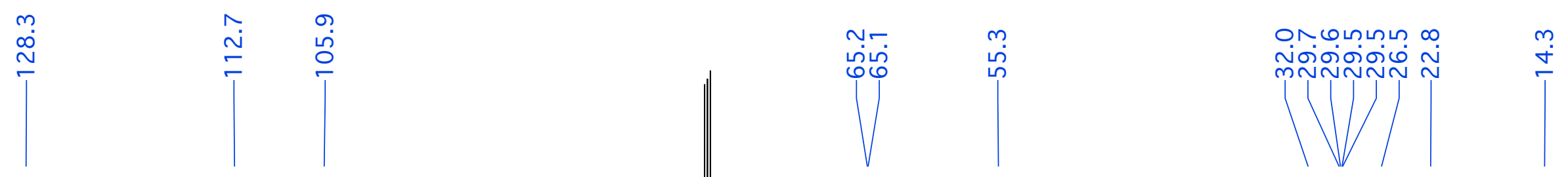

${ }^{13} \mathrm{C}$ NMR spectrum $\left(151 \mathrm{MHz}, \mathrm{CDCl}_{3}\right)$

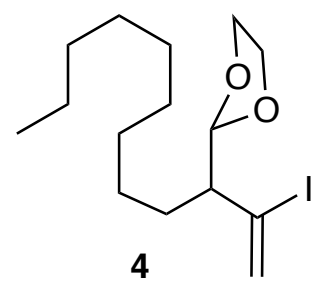


수 í⿴囗十்

${ }^{1} \mathrm{H}$ NMR spectrum (600 $\mathrm{MHz}, \mathrm{CDCl}_{3}$ )

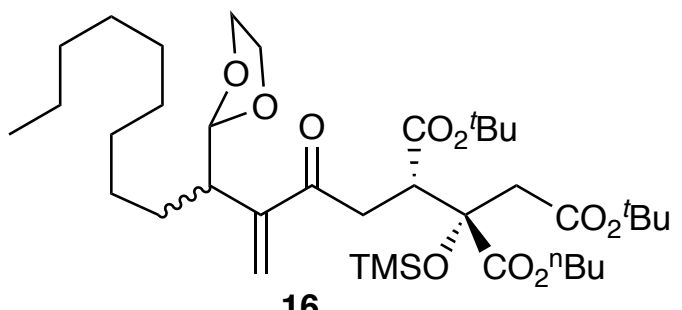

16

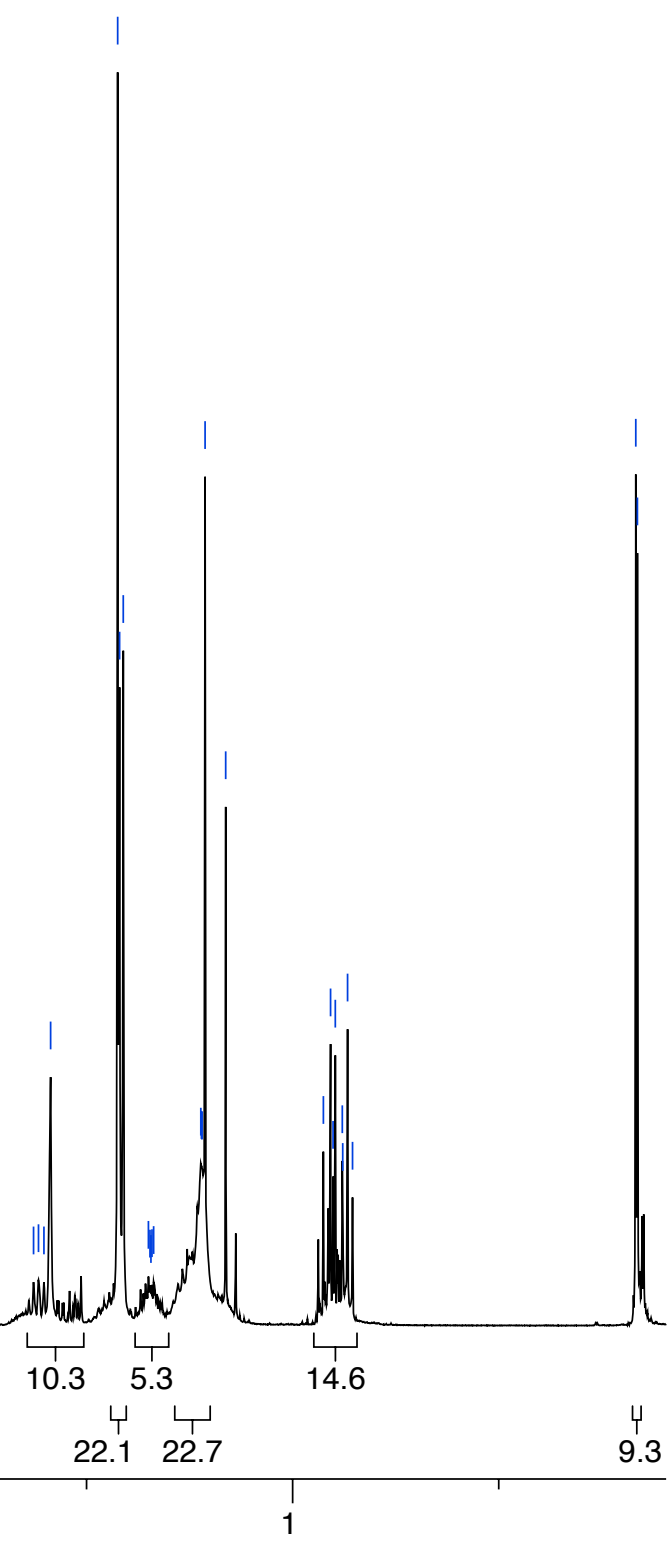




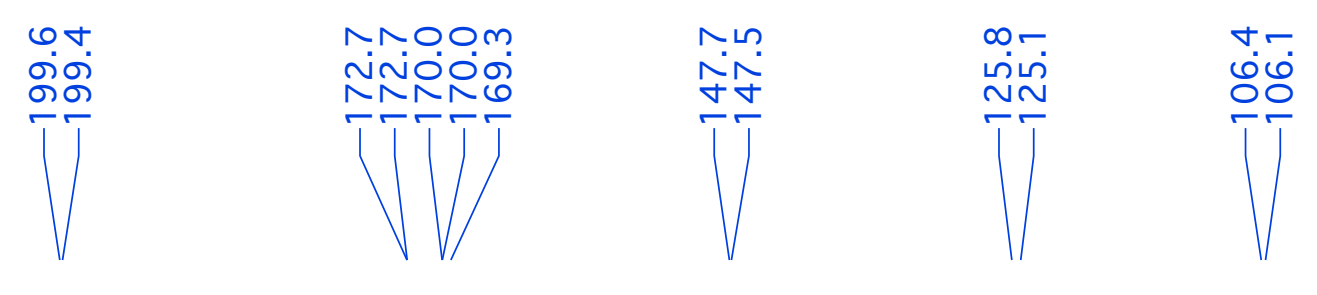

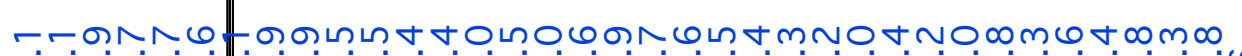
ம்கீ

${ }^{13} \mathrm{C}$ NMR spectrum (151 $\left.\mathrm{MHz} \mathrm{CDCl}_{3}\right)$

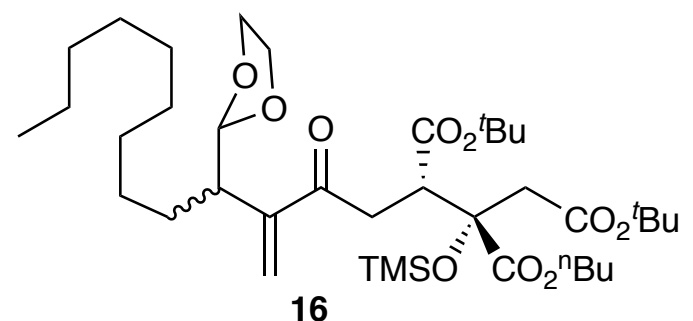

16
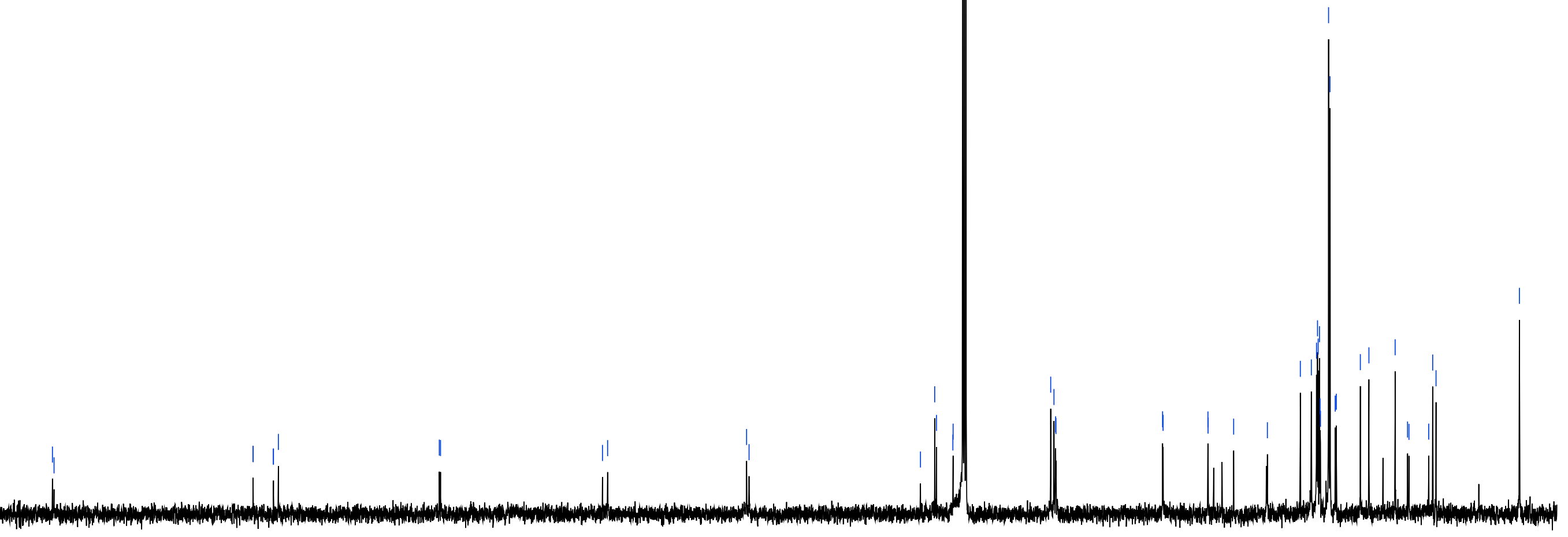
${ }^{1} \mathrm{H}$ NMR spectrum $\left(600 \mathrm{MHz}, \mathrm{CDCl}_{3}\right)$

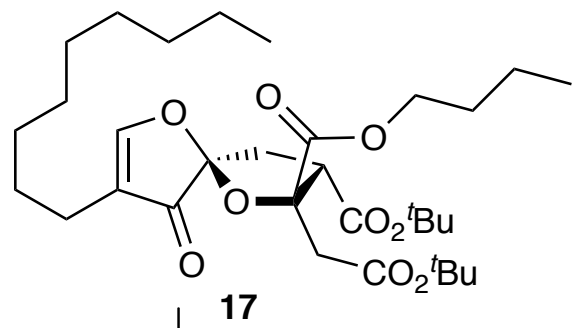

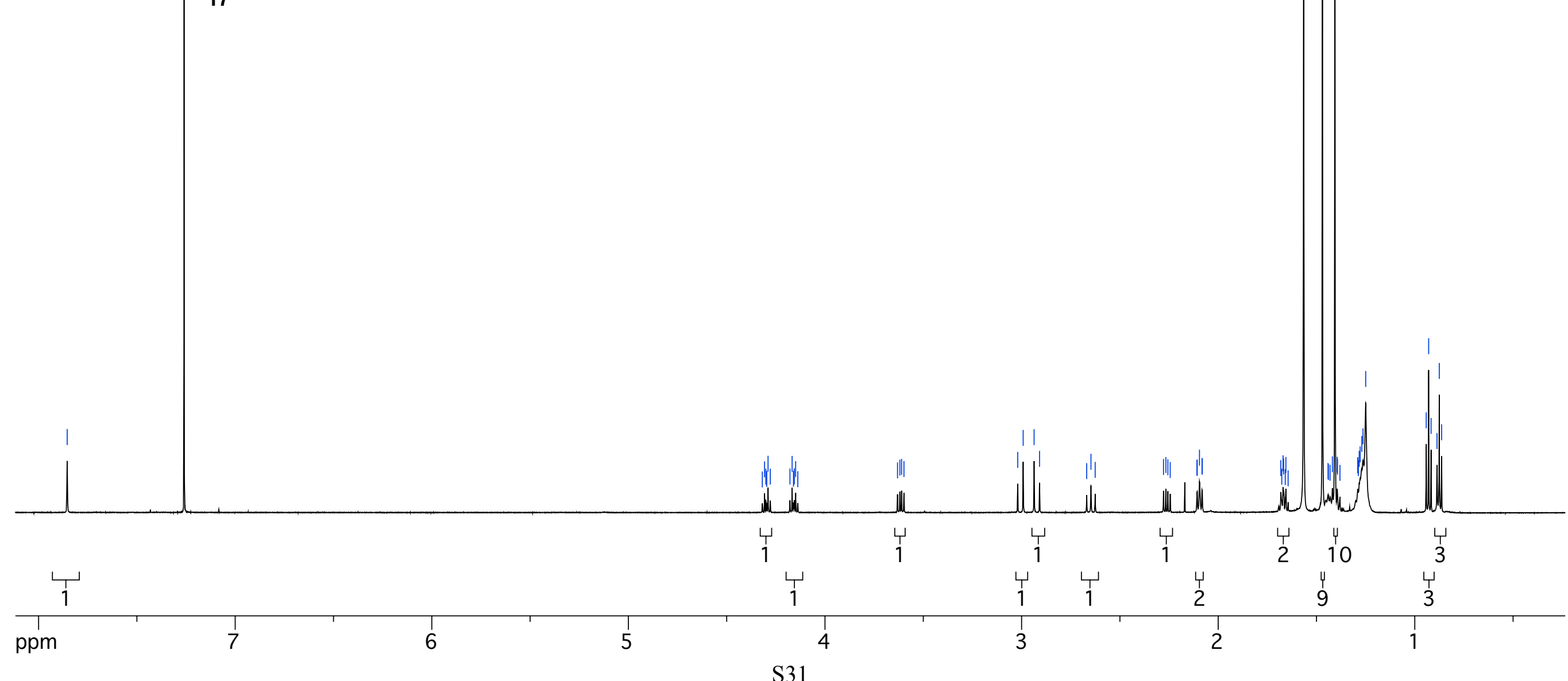




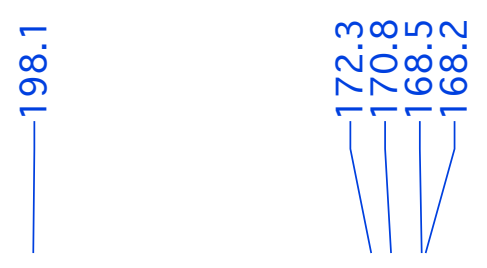

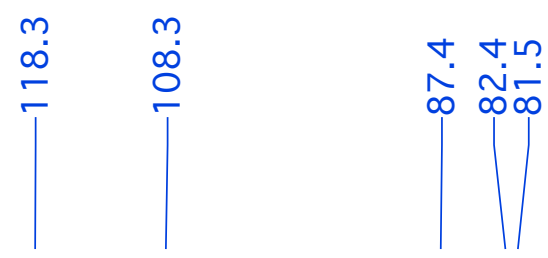

${ }^{13} \mathrm{C}$ NMR spectrum (151 MHz, $\mathrm{CDCl}_{3}$ )
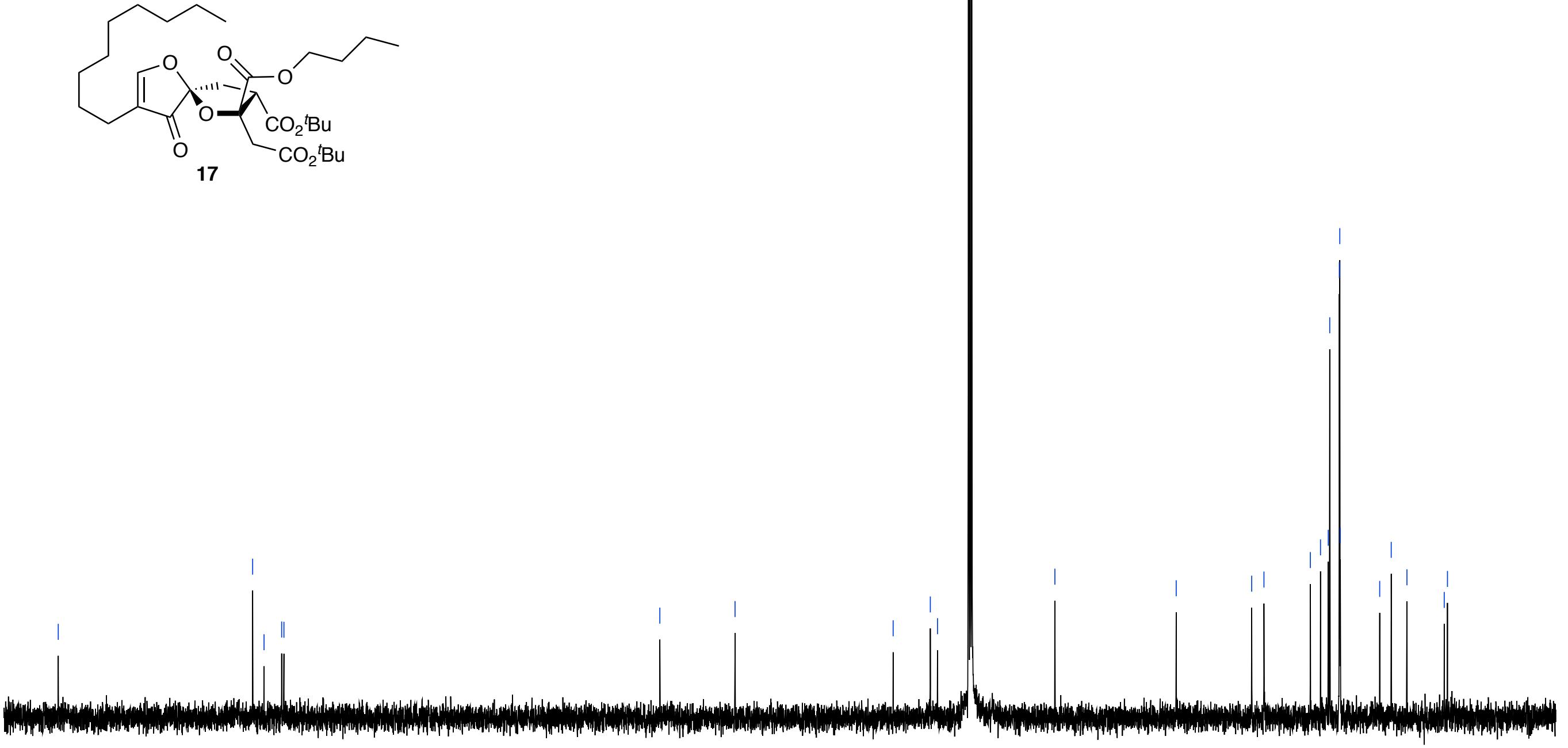
gHMBC spectrum $\left(600 \mathrm{MHz}, \mathrm{CDCl}_{3}\right)$

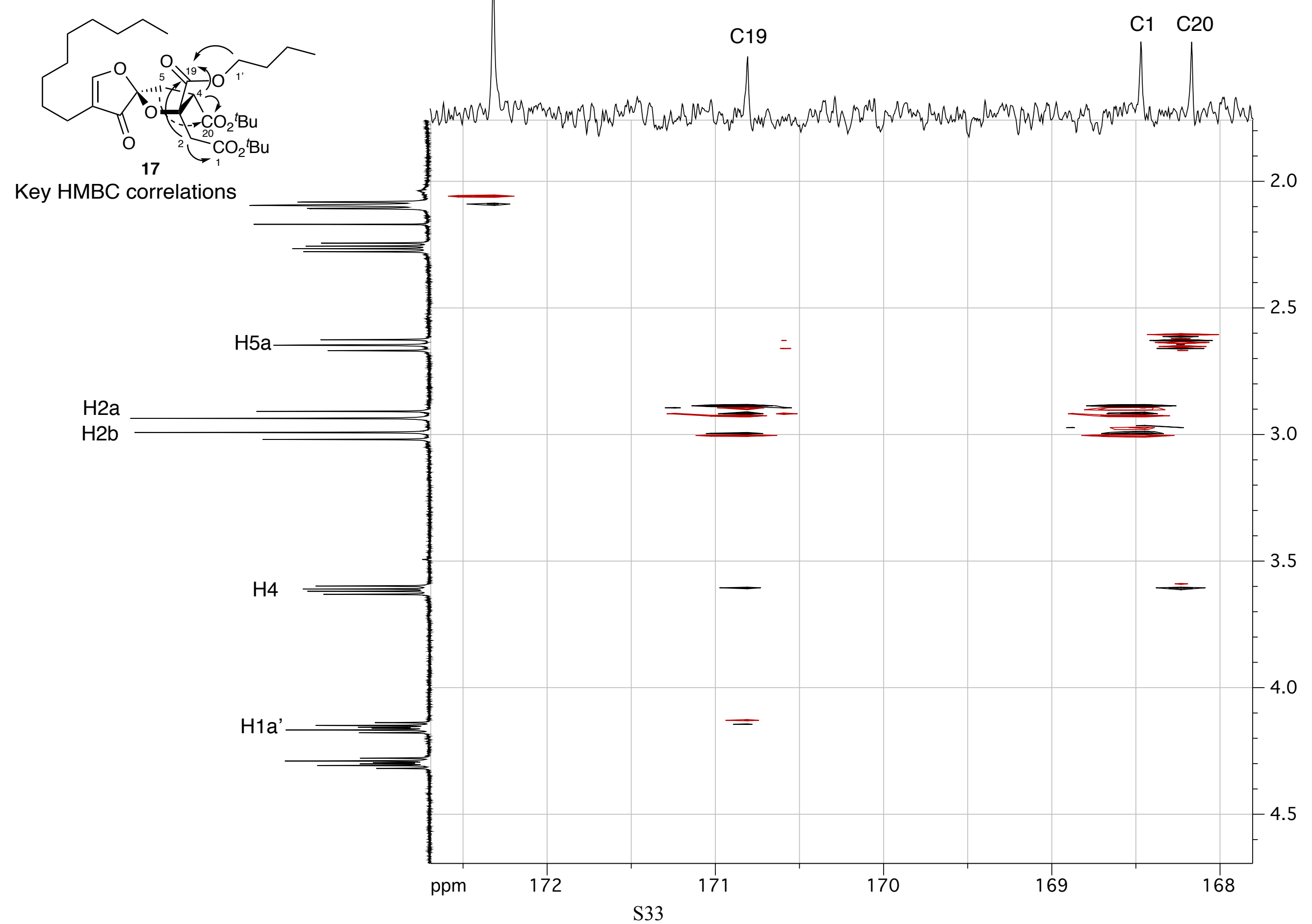




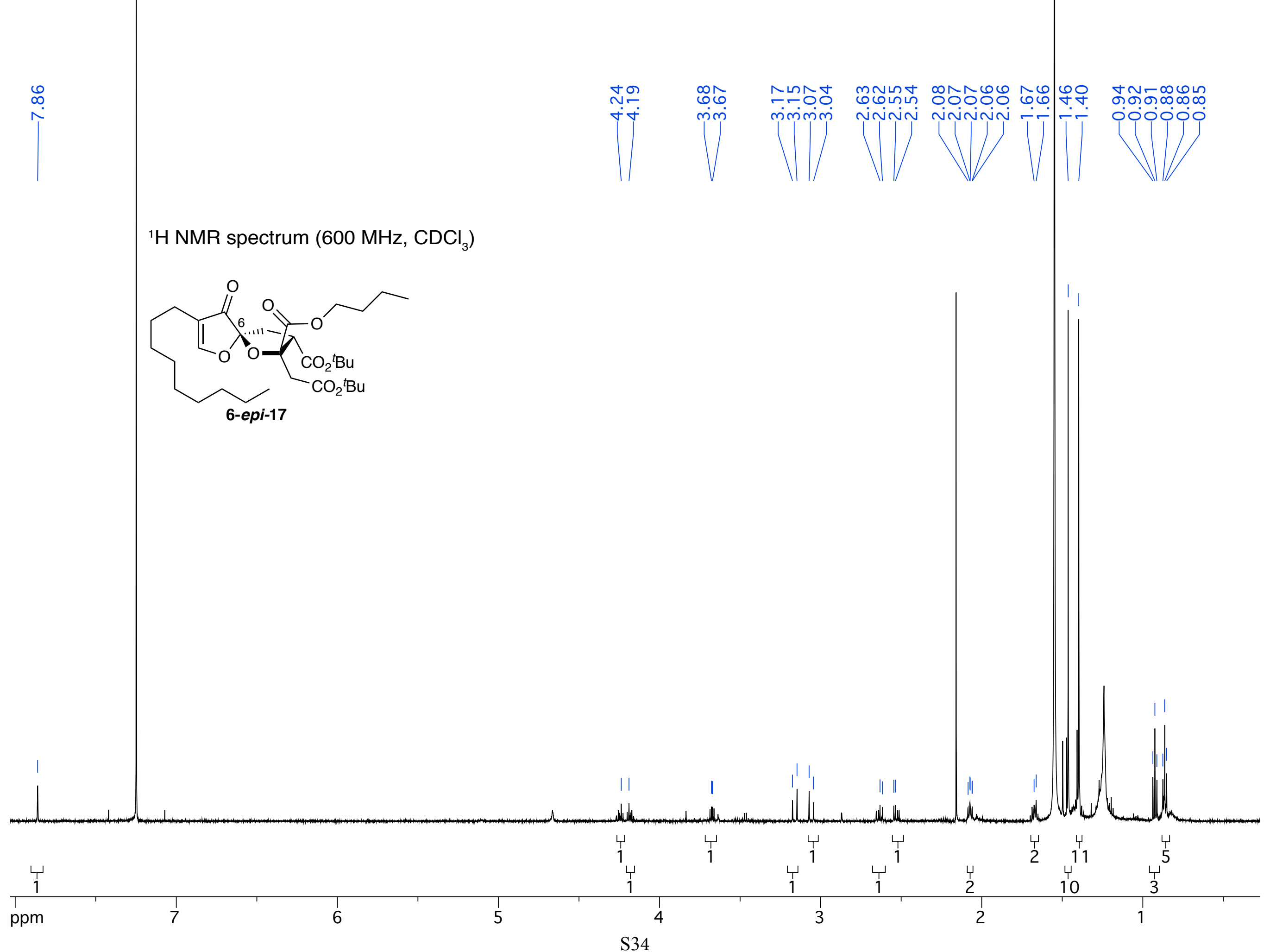



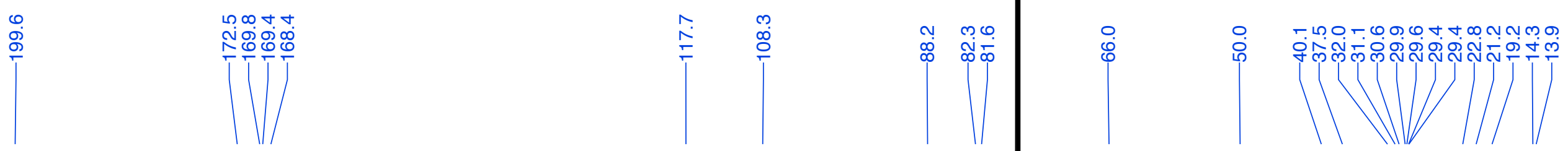

${ }^{13} \mathrm{C}$ NMR spectrum $\left(151 \mathrm{MHz}, \mathrm{CDCl}_{3}\right)$
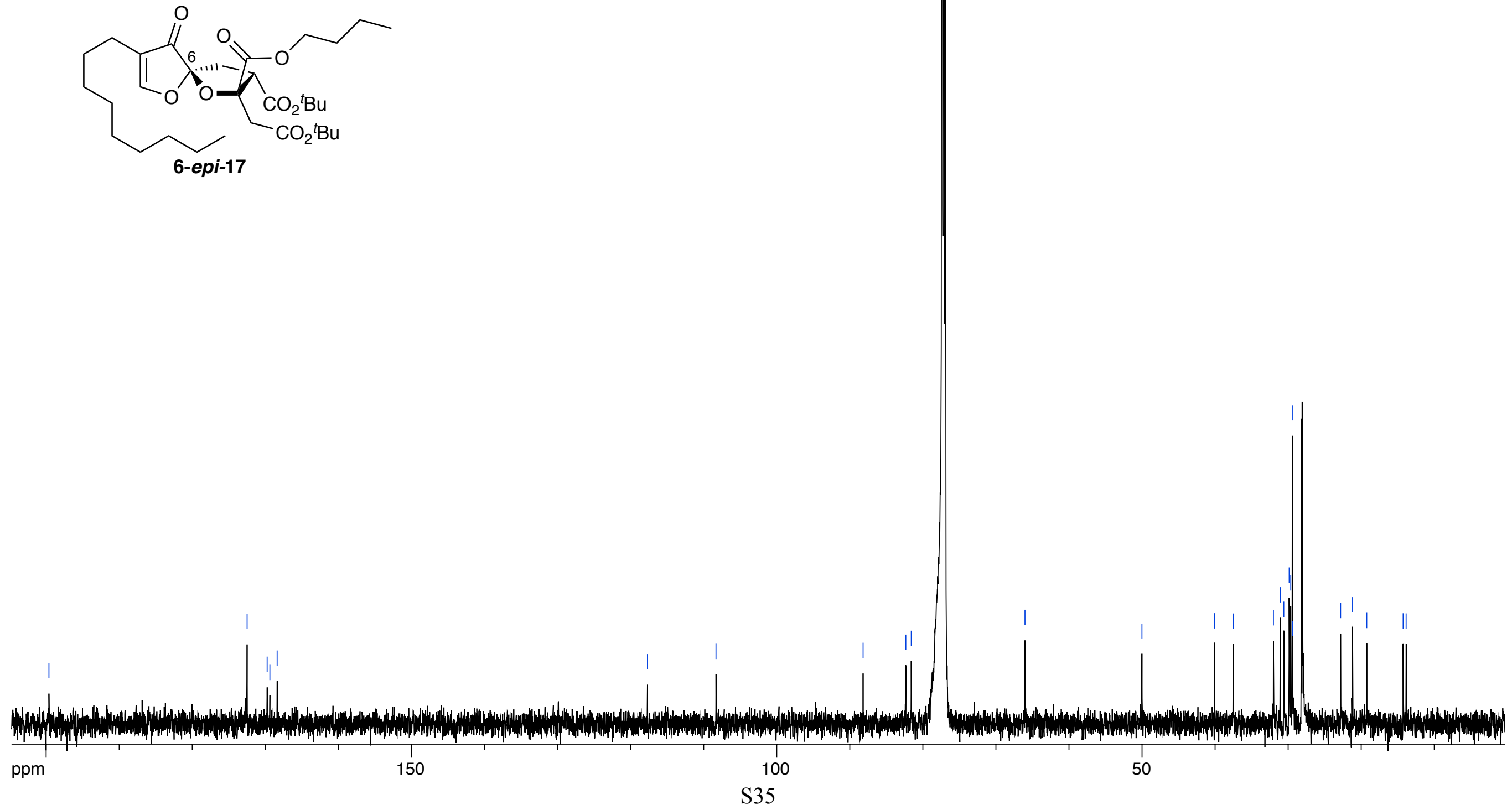
${ }^{1} \mathrm{H}$ NMR spectrum $\left(500 \mathrm{MHz}, \mathrm{CDCl}_{3}\right)$

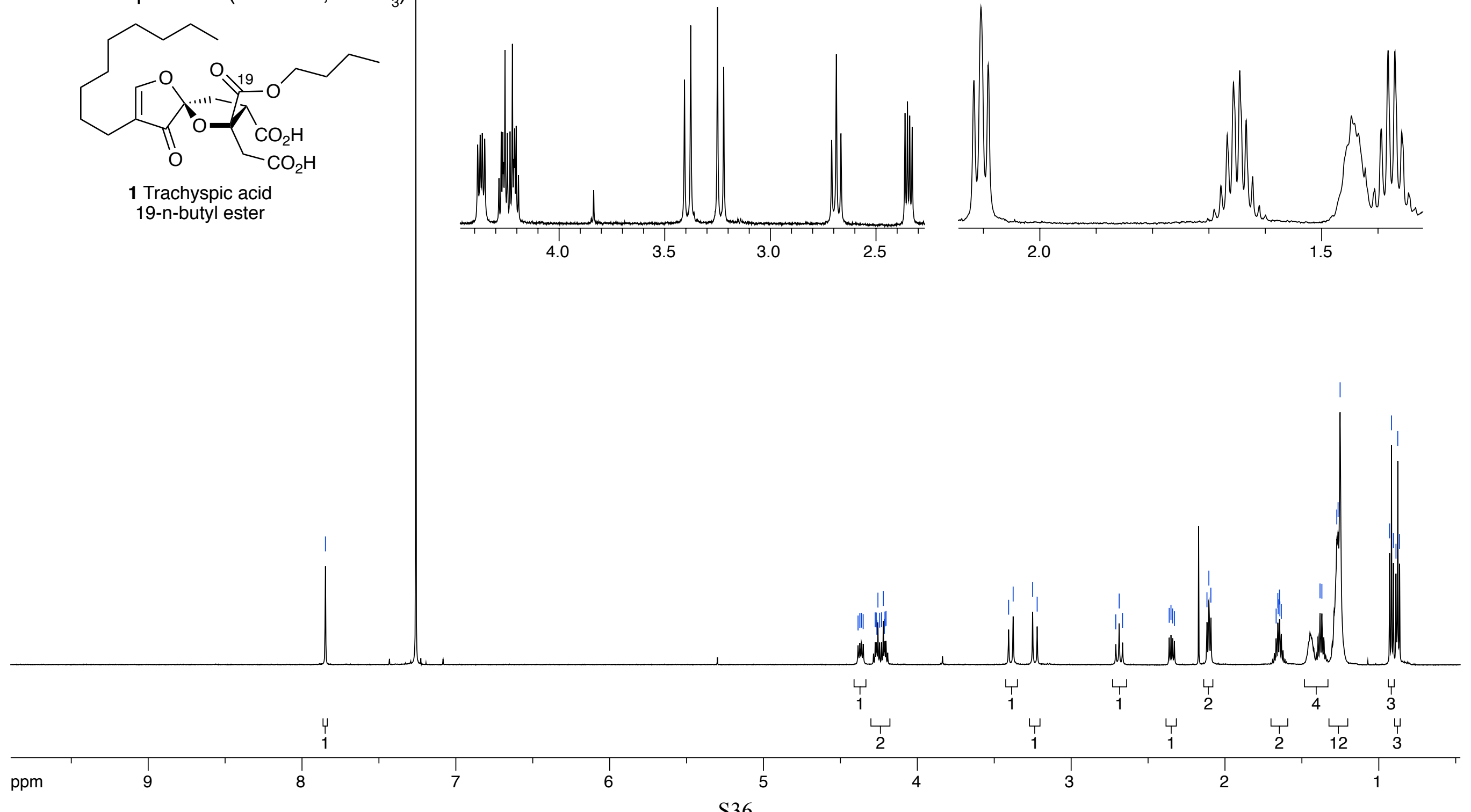

1 Trachyspic acid 19-n-butyl ester
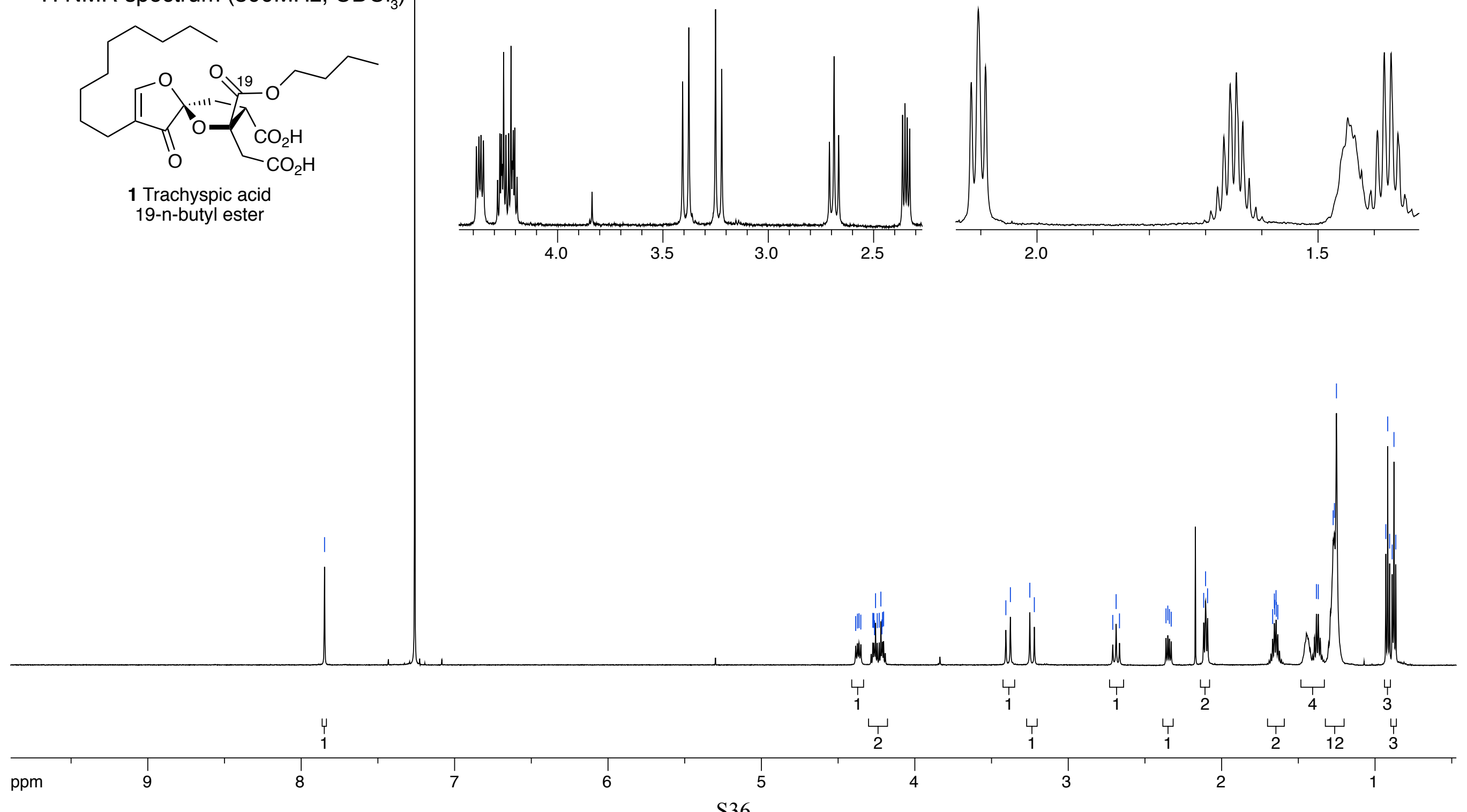

இ t t t H t t t t t m

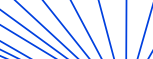


ํํํ

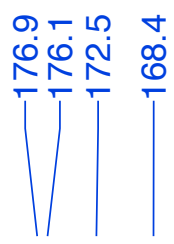

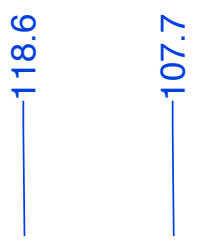

${ }^{13} \mathrm{C}$ NMR spectrum $\left(150 \mathrm{MHz}, \mathrm{CDCl}_{3}\right.$ )

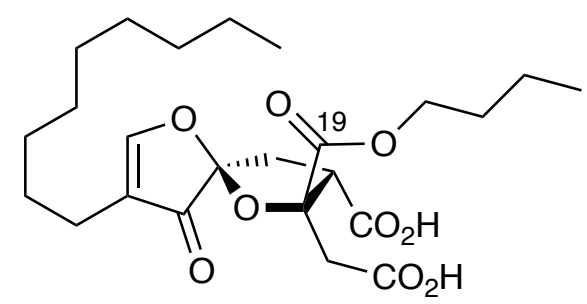

1 Trachyspic acid 19-n-butyl ester
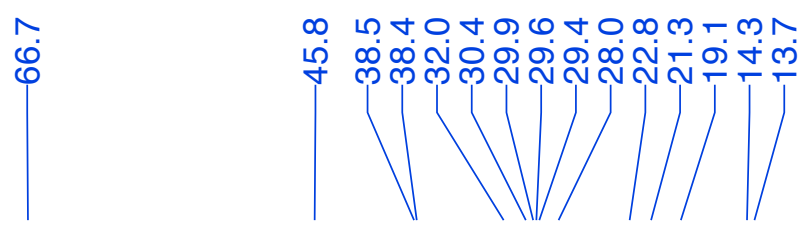

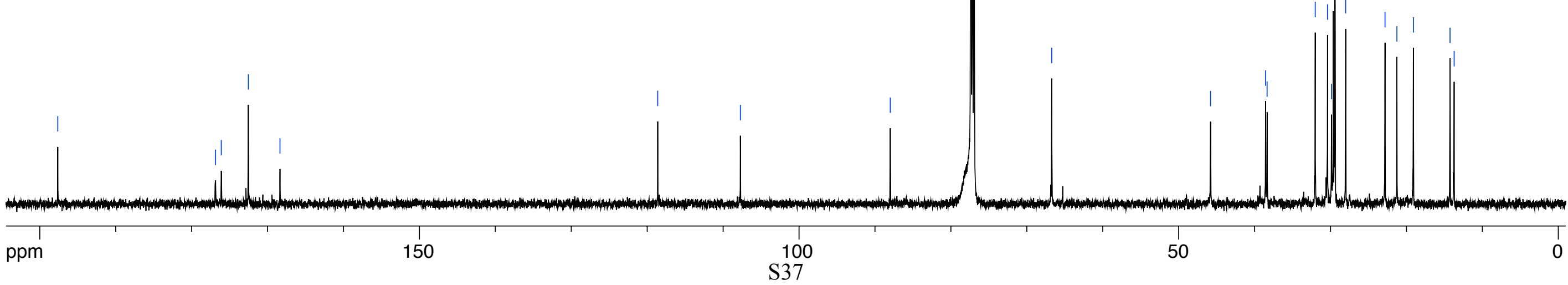

